\title{
A CRITICAL APPRAISAL OF REMEDIES IN THE E.U. MICROSOFT CASES
}

\author{
Nicholas Economides* \\ Ioannis Lianos $\dagger$
}

We discuss and compare the remedies from the European Union's two cases against Microsoft. The first E.U. case ("E.U. Microsoft I") alleged that Microsoft illegally bundled the Windows Media Player with Windows and that Microsoft did not provide adequate documentation that would allow full interoperability between Windows servers and nonMicrosoft servers, as well as between Windows clients and non-Microsoft servers. After finding Microsoft liable and imposing a large fine, the E.U. imposed as remedies two requirements on Microsoft: (1) to sell a version of Windows without Windows Media Player ("Windows-N") and (2) to publish and license interoperability information. Windows- $N$ was a commercial failure, and there has been only limited cross-platform server entry. In its second investigation of Microsoft ("E.U. Microsoft II"), the E.U. alleged illegal tying of Internet Explorer with Windows. The E.U. settled with Microsoft by having them accept the "choicescreen proposal": an obligation to ask consumers whose computers have Internet Explorer pre-installed to choose a browser from a menu of competing browsers through compulsory Windows updates. Thus, the E.U. imposed quite different remedies in the two cases: an unbundling remedy for the Windows Media Player but close to a must-carry requirement for Internet Explorer. We analyze and compare the different approaches.

* Professor of Economics, New York University, Stern School of Business; Executive Director, NET Institute, http://www.netinst.org.

$\dagger$ City Solicitors' Educational Trust Reader in Competition Law and Economics, Faculty of Laws, University College London; Co-Director, Centre for Law and Economics; Associate Executive Director, Jevons Institute of Competition Law and Economics; Co-Director, Centre for Law and Governance in Europe, University College London; Emile Noel Fellow, New York University School of Law. 


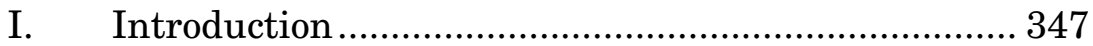

II. The Aim of Competition Law Remedies..................... 350

III. Designing Optimal Remedies and the Roots of the

Microsoft Problem in Europe ..................................... 355

A. Specific (Conduct) Remedies ............................... 357

1. Interoperability/Compatibility....................... 358

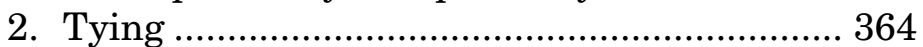

B. Substitutionary Remedies ..................................... 369

1. Fines.......................................................... 370

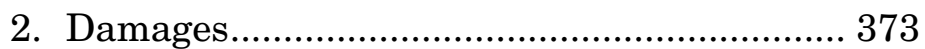

IV. Did the E.U. Microsoft Case Remedies fail? .............. 377

A. The Enforcement Difficulties of the

Interoperability Remedy: Institutional Aspects 377

B. The "Failure" of the Windows-N Remedy and the New Choicescreen Remedy ........................... 382

C. Would a Structural Remedy Have Been an Appropriate Solution to the Microsoft Antitrust Problem? 398

D. Alternative Remedies ......................................... 405

1. Public Procurement Procedures as an Antitrust Remedy: Reducing the Applications Barrier.

2. Standard Setting Organization and de Facto Versus de Jure Standardization.......... 408

V. The Need for a Principle of Remedial

Proportionality

VI. Conclusion 416

\section{INTRODUCTION}

In 2004, the European Commission (Commission) adopted a decision declaring that Microsoft had violated Article 82 of the EC Treaty (now Article 102 Treaty on the Functioning of the European Union) $)^{1}$ by committing two abuses of its

1 Treaty on the Functioning of the European Union (TFEU), art. 102, May 9, 2008, 2008 O.J. (C 115) 47. Article 102 prohibits the abuse of a dominant position by one or more undertakings in a relevant market when there is an affectation of trade between member states. 
dominant position on the market for PC operating systems (E.U. Microsoft I) ${ }^{2}$ Microsoft was held to have abused its dominant position by refusing to supply competitors with certain interoperability information and to allow them to use it for the purpose of developing and distributing competing products on the market for work group server operating systems. It also found that Microsoft had infringed Article 102 TFEU by making the supply of its client PC operating system Windows conditional on the simultaneous acquisition of its Windows Media Player. The General Court (formerly Court of First Instance ${ }^{3}$ ) affirmed the decision of the Commission in $2007 .{ }^{4}$

Following complaints in December 2007 by Opera, the Norwegian Internet browser maker, the Commission initiated investigations and sent a Statement of Objection ("SO") in January 2009. ${ }^{5}$ The SO alleged a violation by Microsoft of Article 102 TFEU for tying its web browser, "Internet Explorer," to its dominant client PC operating system, "Windows." On October 7, 2009, the Commission gave its preliminary approval to the choicescreen proposal and opened it to testing and feedback. ${ }^{6}$ On December 16, the Commission accepted the final choicescreen proposal. ${ }^{7}$

${ }^{2}$ Case COMP/C-3/37.792 Microsoft, Commission Decision of 24 Mar. 2004, available at http://ec.europa.eu/competition/antitrust/cases/decisions /37792/en.pdf (E.U. Microsoft I).

3 The Treaty of Lisbon renamed the Court of First Instance as the General Court. See Treaty on European Union as Amended by the Treaty of Lisbon (TEU), art. 19(1), May 9, 2008, 2008 O.J. (C 115) 13.

${ }^{4}$ Case T-201/04, Microsoft Corp. v. Commission, 2007 E.C.R. II-3601.

${ }^{5}$ See Press Release, Eur. Comm'n, Antitrust: Commission Confirms Sending a Statement of Objections to Microsoft on the Tying of Internet Explorer to Windows (Jan. 17, 2009).

${ }^{6}$ See Press Release, Eur. Comm'n, Antitrust: Commission Market Tests Microsoft's Proposal to Ensure Consumer Choice of Web Browsers; Welcomes Further Improvements in Field of Interoperability (Oct. 7, 2009).

See Case COMP/C-3/39.530 Microsoft, Commission Decision of 16 Dec. 2009, available at http://ec.europa.eu/competition/antitrust/cases/ decisions/39530/final_decision_en.pdf (E.U. Microsoft II). Microsoft's commitments are included in the Annex of the Commission's decision ("Commitments"). In the final settlement, Microsoft made additional 
This study will focus on the remedies that were adopted by the Commission and confirmed by the General Court in E.U. Microsoft I as well as those suggested by Microsoft in E.U. Microsoft II. It will not examine the liability issue or the specific substantive standards for the finding of an abuse of dominant position in E.U. competition law. ${ }^{8}$ Although there will be several references to the remedial strategies adopted in the United States for practices that were closely related to those condemned in the European Microsoft case, this study will also not systematically compare the United States remedy with the E.U. remedy. The reason for this is that each remedy addressed a different competition law problem, and therefore required the adoption of different measures to address that problem.

The study starts by discussing the aim of competition law remedies, before examining the roots of the Microsoft case in Europe and the consequent choice of a remedial approach by the Commission and the Court. It then explores the effectiveness of the remedies in achieving the aims that were set. The non-consideration of the structural remedy in the European case and the pros and cons of developing such a remedy in the future are briefly discussed before more emphasis is put on alternative remedies (competition and non-competition law ones) that have been suggested in the literature. The study concludes by discussing the fit between the remedy and the theory of consumer harm that led to the finding of liability and questions a total dissociation between the two (arguing for a principle of remedial proportionality). We believe that it is important to think seriously about potential remedies before litigation begins. However, we do

commitments on interoperability between rivals' software and its own, including Windows, Windows Server, Office, Exchange, and SharePoint. See Press Release, Microsoft Corp., Microsoft Statement on European Commission Decision (December 16, 2009), available at http://www. microsoft.com/presspass/press/2009/dec09/12-16statement.mspx.

${ }^{8}$ See Nicholas Economides \& Ioannis Lianos, The Elusive Antitrust Standard on Bundling in Europe and in the United States in the Aftermath of the Microsoft Cases, 76 ANTITRUST L.J. 483 (2009) (discussing tying in Microsoft). 
not require an ex ante identification of an appropriate remedy by the plaintiffs, since this could lead to underenforcement or overenforcement.

\section{THE AIM OF COMPETITION LAW REMEDIES}

Competition law remedies are adopted with the aim, among others, to restore competition in the market. ${ }^{9}$ This includes not only the "micro" goals of putting the infringement to an end, compensating the victims, ${ }^{10}$ and curing the particular impediment to competition, but also the "macro" goal of putting incentives in place "so as to minimize the recurrence of just such anticompetitive conduct."11 This study embraces a broader view of the concept of remedies than Council Regulation 1/2003 on the implementation of the rules on competition laid down in Articles 81 and 82 of the Treaty. According to Article 7 of the Regulation, the aim of competition law remedies is "to bring such infringement effectively to an end."12 Remedies can therefore be distinguished from sanctions against undertakings, as the latter have the aim to punish the infringer and to provide compensation to victims or society in general. ${ }^{13}$ This distinction, however, does not adequately

9 See generally A. Douglas Melamed, Afterword: The Purposes of Antitrust Remedies, 76 AnTITRUsT L.J. 359 (2009).

${ }^{10}$ See Robert Pitofsky, Antitrust at the Turn of the Twenty-First Century: The Matter of Remedies, 91 GEO. L.J. 169, 170 (2002) (stating that taking illegal gains from violators and "restor[ing] those monies to the victims" constitutes a principal goal of competition law remedies).

11 Eleanor Fox, Remedies and the Courage of Convictions in a Globalized World: How Globalization Corrupts Relief, 80 TUL. L. REV. 571, 573 (2005).

12 Council Regulation 1/2003, art. 7, 2003 O.J. (L 1) 1 [hereinafter Council Regulation].

13 See OECD, Remedies and Sanctions in Abuse of Dominance Cases, DAF/COMP (2006) 19, at 18 (May 2007), available at http://www. oecd.org/dataoecd/20/17/38623413.pdf ("Typically, remedies aim to stop a violator's unlawful conduct, its anticompetitive effects, and their recurrence, as well as to restore competition. Sanctions are usually meant to deter unlawful conduct in the future, to compensate victims, and to force violators to disgorge their illegal gains."). 
take into account that both sanctions and remedies affect the incentives of the wrongdoers' in their future behavior on the market and thus may lead to the restoration of competition. Thus, this study adopts a broader view of remedies, including stopping the illegal conduct and preventing its recurrence, restoring competition, deterrence, just compensation, and disgorgement of illicit profits. This overall approach provides a more useful framework for analyzing the effect of competition law on the specific market. Furthermore, the restrictive position adopted in Regulation 1/2003 concerns public enforcement and does not take into account the emerging role of private enforcement in E.U. competition law.

Remedies seek generally to restore "the plaintiff's rightful position, that is, to the position that the plaintiff would have occupied if defendant had never violated the law ... [or] to restore the defendants to the defendant's rightful position, that is, the position that the defendant would have occupied absent the violation." ${ }^{14}$ In other words, remedies are a cure to a "wrong" the defendant committed either "in contravention of some legally-recognised right of the plaintiff's" 15 or to a category of right-recipients the legislator aimed to protect (e.g., final or intermediate consumers). The wrong of the defendant gives rise to the enforceable right of the plaintiff (or the protected category) to impose on the defendant a correlative duty of stopping the illegal behavior, paying damages, making restitution, or adopting a specific behavior. Article 7 of Regulation 1/2003 does not oppose this conceptualization of remedies, as it links the adoption of a remedy to the end of the infringement, a concept that might be understood narrowly as the termination of the illegal conduct, but also more broadly as outcome-oriented, thus requiring the reversal of the effects of the illegal conduct.

Therefore, an important aspect in defining remedies is determining who would be the beneficiary of this right; in

14 Douglas Laycock, MOdern American Remedies: CASES AND MATERIALS 2 (1994).

15 Michael Tilbury, Michael Noone \& Bruce Kercher, Remedies: Commentary AND Materials 1 (3d ed. 2000). 
other words, who is the protected category with the right to impose a correlative duty on the defendant. We will assume that the protected category for competition law remedies is the consumers of the relevant market harmed by the "wrong" committed by the defendant. ${ }^{16}$ A wider perspective would be to consider that the protected category consists of the "broader public" who derives benefits from the principle of competition, allegedly jeopardized by the competition law violation. This approach has been taken by the General Court and the European Court of Justice in some recent decisions. ${ }^{17}$

Whichever perspective is chosen, "restoring competition" should not be interpreted as reaching perfect competition (or free competition if one takes a deontological perspective), which is practically unattainable, and in some cases normatively undesirable from a public policy perspective. ${ }^{18}$

16 In this case, consumer welfare or consumer sovereignty will be proxies of consumer harm.

17 See Op. Advocate Gen., Case C-8/08, T-Mobile Netherlands BV v. Raad van bestuur van de Nederlandse Mededingingsautoriteit, III 58, 71 (Feb. 19, 2009), available at http://eurlex.europa.eu/LexUriServ/LexUriServ.do?uri=CELEX:62008C0008:EN:HTML (defending the view that the objective of E.U. Competition law is to "protect . . . competition as such" because this is of benefit, not only for consumers but for "the public at large."). In the judgment, the court accepted that "Article $81 \mathrm{EC}$, like the other competition rules of the Treaty, is designed to protect not only the immediate interests of individual competitors or consumers but also to protect the structure of the market and thus competition as such," but did not adopt the position of AG Kokott with regard to the ultimate beneficiaries of the principle of competition. Case C-8/08, T-Mobile Netherlands BV v. Raad van bestuur van de Nederlandse Mededingingsautoriteit, II 38 (June 4, 2009), available at http://eurlex. europa.eu/LexUriServ/LexUriServ.do?uri=CELEX:62008J0008:EN:HTML. This suggests that a possible interpretation of the aims of E.U. Competition law is the avoidance of a long-term consumer harm. See id. II 36 .

18 In industries with significant network effects, even in the absence of anticompetitive actions, the natural equilibrium is neither perfect competition nor an egalitarian market structure. Markets with strong network effects, such as the market for operating systems of PCs, are "winner-take-most" markets with significant market share and profits inequality as well as high concentration. Thus, the but-for world that 
The remedy aims to restore the market conditions that would have existed in the absence of the conduct found illegal (commonly called the "but for" market conditions).

Competition law remedies also have a prophylactic objective: "[to] ensure that there remain no practices likely to result in monopolization in the future." ${ }^{19}$ This is certainly a difficult enterprise that requires courts to conduct a counterfactual analysis of the situation in the market, both with and without the specific competition law violations. This is particularly difficult in complex and dynamically evolving markets, where static models cannot easily predict the situation that would have existed absent the restraint. It also requires a difficult decision on the appropriate enforcement mechanism for the remedy, as the judge must decide on the degree of her personal involvement in the operation compared to the use of market forces or regulatory institutions. The process of designing appropriate remedies is, perhaps, primarily a decision that regulatory interference is necessary in order to bring the self-correcting forces of the market back to their usual operation, since it is the default mechanism to adjust the incentives of market actors and therefore the interaction between supply and demand in a specific sector of the economy. Thus, remedies could be either (i) setting up conditions for the market to work or (ii) directly influencing or guiding the market.

would have existed in the absence of anti-competitive actions is one of very significant inequality. Attempting to impose the perfectly competitive egalitarian environment of a non-network industry can lead to lower social benefits. See Nicholas Economides, The Economics of Networks, 14 INT'L J. INDUS. ORG. 675, 683 (1996), available at http://www.stern.nyu.edu/ networks/Economides_Economics_of_Networks.pdf; Nicholas Economides, Competition Policy in Network Industries: An Introduction, in THE NEW Economy and Beyond: Past, Present and Future 96 (Dennis W. Jansen ed., 2006), available at http://www.stern.nyu.edu/networks/Economides _Competition_Policy.pdf; Nicholas Economides \& Fredrick Flyer, Compatibility and Market Structure for Network Goods (Stern Sch. Bus., N.Y.U., Discussion Paper EC-98-02, Nov. 1997), available at http://www. stern.nyu.edu/networks/98-02.pdf.

19 See United States v. Microsoft Corp., 253 F.3d 34, 103 (D.C. Cir. 2001). 
There are, of course, different choices that can be made and combined in order to affect the incentives of market actors and restore "competition," which this study, assuming a consumer-driven competition law and policy, defines as the best possible outcome for the consumers of the specific relevant market in terms of price, quality, variety, and innovation. First, it is possible to contract out the remedy to other affected market participants by enabling them to sue for (1) the recuperation of the damages suffered because of the conduct found illegal or (2) for more than the damages incurred in order to deter market participants from adopting a similar anticompetitive conduct in the future. Second, it is possible to develop remedies that would affect market participants' autonomy in their operation of their business, and consequently their incentives. The latter could be conceived as a continuum ranging from remedies that preserve some degree of discretion for market participants (like contractual remedies, such as commitments) to purely non-voluntary schemes, unilaterally imposed by the public authorities. One could also distinguish remedies that relate to the conduct of the market participants and attempt to affect their incentives to adopt a specific form of conduct (by creating disincentives such as fines, or more harshly, by imposing injunctions, interdictions, or conduct remedies) from more intrusive remedies that affect the infringing company's assets (structural remedies ${ }^{20}$ ) or the management's status (criminal sanctions). ${ }^{21}$

${ }^{20}$ Article 7 of Council Regulation 1/2003 traditionally distinguishes between structural and behavioral remedies, without providing a definition for each of these two concepts. See Council Regulation, supra note 12. But see Per Hellström, DG Competition, Remedies under Article 82 EC, http://www.justice.gov/atr/public/hearings/single_firm/docs/222446 .htm (last visited Apr. 9, 2010), defining a structural remedy (including divestiture of a controlling stake, of a business unit, of a package of assets, or of a long-term exclusive license) as:

a measure that effectively changes the structure of the market by a transfer of property rights regarding tangible or intangible assets, including the transfer of an entire business unit, that does not lead to any ongoing relationships between the former and the future owner. 


\section{DESIGNING OPTIMAL REMEDIES AND THE ROOTS OF THE MICROSOFT PROBLEM IN EUROPE}

The design of optimal remedies requires a clear identification of the competition law problem that the antitrust remedy is attempting to address. It may be that competition authorities and courts develop different remedial strategies for analogous fact patterns because the competition law problems that were identified as the source of consumer harm in the liability phase of the decision are different. This study builds on the assumption that consumers should be at the center of the attention of competition law enforcers, not only at the liability phase of the decision, but also at the remedy phase.

Whenever there is a finding of a competition law violation there is always a consumer harm story in the background, a narrative of consumer harm that is built on specific

After its completion, a structural remedy should not require any further monitoring.

The distinction between structural and behavioral remedies is not, however as clear-cut as Regulation 1/2003 suggests. In its Merger Remedies Study, the European Commission set aside the distinction between structural and behavioral remedies and adopted a wider classification that distinguished remedies involving the transfer of a market position, those involving exit from a joint venture and remedies relating to access granting. See DG Competition, European Commission, MERGER REMEDIES STUDY 17-19 (2005), available at http://ec.europa.eu/ competition/mergers/legislation/remedies_study.pdf; see also Gotz Drautz, Remedies under the Merger Regulation, in ANNUAL PROCEEDINGS OF THE Fordham Corporate LAW Institute 219, 225 (Barry Hawk ed., 1996) (noting that "the distinction between these two types of remedies is not a clear bright line and, in fact, it appears that the line has been 'moving' over time" and offering examples of hybrid (mixed) remedies involving both structural and behavioral elements).

${ }^{21}$ Criminal sanctions are imposed on individuals, as opposed to undertakings, excluding the circumstances when individuals might be also qualified as undertakings under Article 101 or 102 TFEU. See generally Peter Whelan, A Principled Argument for Personal Criminal Sanctions as Punishment Under EC Cartel Law, 4 Competition L. Rev. 7 (2007); Wouter Wills, Is Criminalization of EU Competition Law the Answer?, 28 WORLD COMPETITION L. \& ECON. REV. 117 (2005). 
inferences from the facts of the case and that is established by different types of evidence. In order to understand and assess the remedies adopted in the Microsoft case, we need to unravel the narrative of consumer harm that led to the adoption of these specific remedies. Additionally, often actions can be identified as having an anticompetitive effect, but the quantification of that effect is much more difficult. Thus, a full restoration of the market to the "but for" world may be unfeasible. Often all that can be done is to eliminate the impediments to competition that resulted from anticompetitive actions.

In Europe, there were two dominant narratives of anticompetitive effect in E.U. Microsoft I: first, an issue of lack of interoperability and compatibility that allegedly harmed consumers; second, a story of illegal tying of Windows with Windows Media Player. ${ }^{22}$ Both stories relate to the business strategy of Microsoft to integrate different applications in its Windows platform, which was also the source of Microsoft's troubles in the United States. ${ }^{23}$ However, there are different views on the anticompetitive effects of this strategy of integration. While in the United States the main "story" of anticompetitive harm was that Microsoft was essentially attempting to preserve the dominance of the Windows' platform, ${ }^{24}$ in Europe the Commission and the Court perceived Microsoft's strategy as essentially being focused on the application part of the business, where it attempted to extend its dominant position through the network effects of its platform. ${ }^{25}$ The different

${ }^{22}$ E.U. Microsoft I, supra note 2, II 545.

${ }^{23}$ In the United States, some of the main issues were: (1) integration of Internet Explorer into the Windows Operating System, see United States v. Microsoft Corp., 253 F.3d 34, 64 (D.C. Cir. 2001), and (2) illegal tying of Internet Explorer with Windows, id. at 84.

${ }^{24}$ The leveraging attempted monopolization part of the browser market claim was not successful. See id. at 80-81.

${ }_{25}$ Case T-201/04, Microsoft Corp. v. Commission, 2007 E.C.R. II-3601, III 1288, 1327, 1344 ("[I]t must be borne in mind at the outset that the two abuses at issue form part of a leveraging infringement, consisting in Microsoft's use of its dominant position on the client PC operating systems market to extend that dominant position to two adjacent markets, namely 
narratives of anticompetitive effect justified the choice of a different remedial strategy.

Institutional differences between Europe and the United States may also explain the different remedy mixture in each jurisdiction. Fines are frequently imposed in Europe, while civil remedies (fines) are unavailable in the United States for infringements of $\S \S 1$ and 2 of the Sherman Act; furthermore, private enforcement and damages actions are less frequent in Europe than in the United States. Although the beneficiaries are different for fines than for damages actions (taxpayers for the first, consumers for the second), there is a close relation between civil sanctions and damages from a deterrence perspective, as both forms of relief increase the overall cost of being caught.

The alleged narrative of anticompetitive effect is intrinsically related to the imposition of a specific duty to the defendant to cure the wrong the defendant committed. It therefore affects the mixture of the different types of remedies adopted. In some cases, that will require the adoption of a specific duty to act (conduct remedies). In other cases, it will entail a substitutionary (pecuniary) remedy, often when it is difficult or impossible to cure all the negative effects of the practice on the protected category with conduct remedies.

\section{A. Specific (Conduct) Remedies}

The Commission adopted conduct remedies for both anticompetitive practices of Microsoft. These remedies should respect the usual requirements of proportionality ${ }^{26}$

the market for work group server operating systems and the market for streaming media players.").

${ }^{26}$ Case 15/83, Denkavit Nederland BV v. Hoofproduktschap voor Akkerbouwprodukten, 1984 E.C.R. 2171, II 25; Case C-331/88, The Queen v. Minister of Agric., Fisheries and Food ex parte Fedesa, 1990 E.C.R. I4023, II 13; Case C-354/95, The Queen v. Minister of Agric., Fisheries \& Food ex parte Nat'l Farmers' Union, 1997 E.C.R. I-4559, III 49, 50. The main aspects of the principle are that the measures should (1) be appropriate to achieve the legitimate aim in question (finality test), (2) be no more onerous that is required to achieve that aim (necessity test), and 
and the existence of a relation between the remedy and the infringement that has been established. ${ }^{27}$ The first remedy addressed the interoperability/compatibility issue, the second the tying/leveraging issue.

\section{Interoperability/Compatibility}

The Commission found that Microsoft had refused to provide Sun with information enabling it to design work group server operating systems which could seamlessly integrate in the "Active Directory domain architecture," a web of interrelated client-PC-to-server and server-to-server protocols that organize Windows work group networks. Microsoft's refusal to provide interoperability to Sun was found to be part of a broader pattern of refusing interoperability to any vendor of work group server operating systems. Microsoft developed this strategy after it had, for a certain period of time, provided the necessary information for previous versions of Microsoft's products to Sun and to the industry at large. The Commission found that this disruption of previous levels of supply eliminated competition in the relevant market for work group server operating systems, as this information was indispensable for competitors operating in that market. ${ }^{28}$

According to the Commission, Microsoft attempted to leverage the quasi-monopoly power it had in the operating system market to the work group server market. ${ }^{29}$ Due to network effects, Windows is an indispensable platform for most applications. The Commission found evidence that there was a link between the enhanced interoperability of Microsoft's group server operating systems relative to competing group server operating systems, and the rapid

(3) be the least onerous, if there is a choice of equally effective measures (less restrictive alternative test).

${ }^{27}$ Joined Cases $6 \&$ 7/73, Instituto Chemioterapico Italiano S.p.A \& Commercial Solvents Corp. v. Commission, 1974 E.C.R. 223, II 45; Case T170/06, Alrosa Co. v. Commission, 2007 E.C.R. II-2601, II 131.

${ }^{28}$ E.U. Microsoft I, supra note 2, III 584, 692.

${ }^{29}$ Id. II 772. 
rise to dominance of Microsoft's applications in the group server operating system market. ${ }^{30}$ The Commission proceeded even further and argued that Microsoft's actions had caused consumer harm, claiming that because of Microsoft's refusal to provide interoperability, competitors were not able to provide new and enhanced products to consumers. ${ }^{31}$ However, the Commission did not provide any evidence that projects to develop new products had not been carried out because of Microsoft's conduct. The Commission proceeded to a qualitative balancing of the incentives of Microsoft and its competitors to innovate in the marketplace and concluded that Microsoft had committed an abuse of a dominant position sanctioned under Article 102. ${ }^{32}$ According to the Commission, imposing a duty to provide interoperability would not reduce Microsoft's incentives to innovate (because this is the way competition takes place in this industry), and would preserve the incentives of Microsoft's competitors to innovate. ${ }^{33}$

In adopting its conclusion on Microsoft's liability, the Commission was indirectly influenced by the existence of previous case law addressing problems of interoperability in the software sector. ${ }^{34}$ In fact, although the decision of the Commission targeted the refusal of interoperability by Microsoft to Sun, it is clear from the general description of the competition law problem with which the Commission was confronted that it envisioned the issue of interoperability more broadly than the confines of the facts of the specific case. For example, the Commission referred to

${ }^{30}$ Id. II 781.

31 Id. III $694,782$.

32 For analysis, see Ioannis Lianos, Competition Law and Intellectual Property Rights: Is the Property Rights' Approach Right?, in CAMBRIDGE YEARBOOK OF EuRopean LEGAL Studies 153 (John Bell \& Claire Kilpatrick eds., 2006).

${ }^{33}$ E.U. Microsoft I, supra note 2, II 725.

${ }^{34}$ Id. III 736-42 (citing Commission Case IV/29.479, IBM (recognizing that "active disclosure of intellectual property-protected information and licensing of intellectual property could be necessary to allow for interoperability")). Id. II 740 . 
the strong network effects that existed in this market and made it far more difficult for Microsoft's competitors to contest Microsoft's dominance in the platform and application parts of its business. The Commission also emphasized the "strong commercial and technical associative links" between the PC operating system market and the work group server operating system market which make it so that "Microsoft's dominance over the PC operating system market has a significant impact on the adjacent market for operating systems for work group servers." ${ }^{35}$ This observation communicates the idea that the competition problem confronting the Commission was structural (relating to the nature of the market and the existence of barriers to entry) and that therefore the development of a set of remedies that would address the problem of interoperability at its core were necessary.

The Commission referred to previous industry practice, in particular the license agreement with AT\&T relating to the disclosure of portions of the Windows source code, ${ }^{36}$ to previous decisional practice, such as the IBM precedent, ${ }^{37}$ and to the existing regulatory framework in the software sector as specific illustrations of the need to establish interoperability. Indeed, the EC Software Directive adopted in $1991^{38}$ restricted the exercise of copyright over software (including exercise by non-dominant undertakings) for interoperability reasons and explicitly provided that its provisions were without prejudice to the application of Article 102, including when a dominant undertaking refused to make available information which is necessary for

${ }^{35}$ E.U. Microsoft I, supra note 2, III 526, 532; Case T-201/04, Microsoft Corp. v. Commission, 2007 E.C.R. II-3601 II 526.

${ }^{36}$ E.U. Microsoft I, supra note 2, II 211.

${ }^{37}$ Commission Case IV/29.479, IBM, available at http://www.cptech. org/at/ibm/ibm1984ec.html.

38 Council Directive 91/250/EEC, Legal Protection of Computer Programs, 1991 O.J. (L 122) 42, now replaced by Council Directive 2009/24/EC, Legal Protection of Computer programs, 2009 O.J. (L 111) 16. 
interoperability. ${ }^{39}$ The need to guarantee interoperability is an important feature of both industry practice and regulation of the software sector.

The main objective of the remedy created by the Commission was thus to restore interoperability, at least to the same degree that existed on the market before the alleged disruption by Microsoft of the previous supply of information. This raised two difficulties.

First, the Commission had to define the requisite degree of interoperability. This is an issue linked to both the liability and the remedy parts of the decision. Microsoft argued that it already provided some form of interoperability, but the Commission found this to be insufficient, as this degree of interoperability was still providing an advantage to Microsoft's work group server operating systems. ${ }^{40}$ The issue could be framed as a platform neutrality problem: here, a platform owner also provided complementary goods or services (applications) which relied on the platform and which competed with other applications. Had Microsoft not provided full (or native) interoperability to its own work group server operating systems, after providing the same degree of interoperability in the past with competing applications, most likely the Commission would not have found a violation of Article 102 TFEU. The Commission understood interoperability in relative (not absolute) terms, requiring the same level of interoperability in systems composed of components of different companies than that achieved between the components of the same platform, if this is controlled by a dominant undertaking. This created a paradox as the Active Directory did not exist in the past (before Windows 2000) and Microsoft had not provided interoperability information in the past. Rather, Microsoft provided a license to the source code of Windows itself, for others (mainly AT\&T) to use to build bridges

39 Council Directive 91/250/EEC, supra note 38, recital 24; Council Directive 2009/24/EC, supra note 38, recital 17; see also Case T-201/04, Microsoft Corp. v. Commission, 2007 E.C.R. II-3601, II 763.

${ }^{40}$ E.U. Microsoft I, supra note 2, III 691, 781. 
between UNIX and Windows. ${ }^{41}$ But providing Windows source code was not what the Commission wanted Microsoft to do.

The disclosure requirement that the Commission imposed on Microsoft applied prospectively to future generations of Microsoft's products, thus implying that Microsoft should update the disclosed information each time it brought to market new versions of its products. ${ }^{42}$ The aim of the remedy was clearly to enhance the ability of Microsoft's competitors to "develop products that interoperate with the Windows domain architecture ... and hence viably compete with Microsoft's work group server operating system.." ${ }^{43}$

Second, the Commission had to decide the institutional arrangement that would best achieve the required degree of interoperability. This issue relates to the implementation mechanism for the remedy, which raised important difficulties in this case. Article 7 of the Commission's liability decision required Microsoft to submit a proposal to the Commission "for the establishment of a suitable mechanism assisting the Commission in monitoring Microsoft Corporation's compliance." The complexity of the decision, and in particular the need to constantly verify the accuracy and completeness of the information provided by Microsoft, as well as the need to provide adequate information on specifications, requires, in some circumstances, the inspection of Microsoft's source code in order to resolve any issue of accuracy and completeness of the specifications disclosed. The Commission thus decided to appoint a monitoring trustee. ${ }^{44}$ The monitoring trustee was

\footnotetext{
${ }^{41}$ Id. II 211.

Id. II 1002.

${ }^{43}$ Id. II 1003.
}

${ }^{44}$ E.U. Microsoft I, supra note 2, art. 7. The Commission appointed as Monitoring Trustee Professor Neil Barrett, a computer scientist, from a shortlist of four experts submitted by Microsoft in October 2005. See Press Release, Eur. Comm'n, Competition: Commission Appoints Trustee to Advise on Microsoft's Compliance with 2004 Decision (May 10, 2005), http://europa.eu/rapid/pressReleasesAction.do?reference=IP/05/1215\&form at $=$ HTML\&aged $=0 \&$ language $=E N \&$ guiLanguage $=$ en (last visited Apr. 9, 2010). 
asked to adopt a proactive, rather than reactive, role in enforcing the interoperability, as well as the tying, part of the decision. ${ }^{45}$ The compliance process for the interoperability part of the decision faced difficulties that led to a number of exchanges between the Commission and Microsoft and eventually a number of Article 24 Regulation $1 / 2003$ penalty decisions. ${ }^{46}$

Following the judgment of the General Court confirming the Commission findings on Microsoft's liability for refusing to supply interoperability and tying, ${ }^{47}$ Microsoft agreed with the Commission to alter a certain number of the conditions in its license agreements regarding the provision of interoperability information (the October 2007 Neelie KroesSteve Ballmer agreement). ${ }^{48}$ Two months later, the

${ }^{45}$ E.U. Microsoft I, supra note 2, II 1046. The European Commission's decision had the advantage of intervening at a later stage when the United States experience could have been very instructive for the design of the interoperability remedy. For an excellent account of the United States experience, see William H. Page \& Seldon J. Childers, Software Development as an Antitrust Remedy: Lessons from the Enforcement of the Microsoft Communications Protocol Licensing Requirement, 14 MICH. Telecomm. \& Tech. L. Rev. 77 (2007); William H. Page, Mandatory Contracting Remedies in the American and European Microsoft Cases (U. Fla., Levin C. L. Research Paper No. 2009-22, 2009), available at http://ssrn.com/abstract=1073103.

46 See Council Regulation, supra note 12, art. 24 (stating that where an infringement has been established by a previous Commission antitrust decision, the commission may impose penalty payments up to five percent of the average daily turnover in the proceeding business year per Calendar day to compel the company to end the infringement). Here, the Commission first warned Microsoft in November 2005 that it could face a daily fine of up to $€ 2$ million if it did not comply. Case COMP/C-3/37.792 Microsoft, Commission Decision of 10 Nov. 2005, available at http://ec.europa.eu/competition/antitrust/cases/decisions/37792/art24_1_de cision.pdf. The Commission then imposed a €280.5 million fine for noncompliance. Case COMP/C-3/37.792 Microsoft, Commission Decision of 12 July 2006.

${ }^{47}$ See Case T-201/04, Microsoft Corp. v. Commission, 2007 E.C.R. II3601.

48 See William H. Page \& Seldon J. Childers, Bargaining in the Shadow of the European Microsoft Decision: The Microsoft-SAMBA Protocol License, 102 Nw. U. L. REV. ColloQuy 332, 343-44 (2008) 
Commission supported the conclusion of a licensing agreement between Microsoft and Samba (the Protocol Freedom Information Agreement, or "PFIF Agreement"). ${ }^{49}$ Microsoft was willing to provide, as an annex to the agreement, an indication of all the patents it claimed in its licensed information and agreed not to sue Samba for infringement of any unlisted patent. ${ }^{50}$ These "patent maps," which have also become a prominent feature of Microsoft's interoperability policy ${ }^{51}$ provide developers an opportunity to attempt to successfully design around the protocols without risk of patent infringement. Microsoft has only included patents on the patent map that it believes are necessarily infringed by implementation of the protocol. The Samba license constitutes the most important development of the E.U. Microsoft Decision's remedial phase.

\section{Tying}

In comparison to the complex and long-standing compliance required by the decision's interoperability component, the conduct remedy imposed with regard to the tying violation was relatively straightforward. The 2004 Commission Decision took the view that Microsoft had violated Article 102 TFEU by attempting to leverage its quasi-monopolistic position in the PC operating systems market into the media player market. As explained in the Commission's decision, the United States Judgments did not solve that particular anticompetitive problem. ${ }^{52}$ First, the United States proceedings focused only on the maintenance

(discussing this initial agreement in licensing protocols, which eventually gave rise to the Microsoft-SAMBA agreement).

${ }^{49}$ PFIF was a nonprofit corporation created by the Software Freedom Law Center (SFLC) in order to license the documentation to free or open source developers. The PFIF Agreement made the protocol information available to Free Software projects like SAMBA. See id. at 344-45.

${ }^{50}$ Id. at 347.

51 See Microsoft Corp., Interoperability Principles Patent Maps, http://www.microsoft.com/openspecifications/programs/other/interoperabili ty-principles-patent-maps/ (last visited Apr. 7, 2010).

52 See E.U. Microsoft I, supra note 2, III 688-91. 
of monopoly argument. The plaintiffs abandoned the tying claim after the Court of Appeals ruled that technological tying should be examined under a rule of reason. ${ }^{53}$ Second, because the plaintiffs in the United States did not pursue the tying claim, there was no specific remedy included for tying: ${ }^{54}$ the United States judgment provided no means for the Original Equipment Manufacturers ("OEMs") and endusers to remove Windows Media Player code from the PC operating system (as it was technically unfeasible to remove the Windows Media Player code without running the risk that other parts of the operating system and third party products relying on Windows Media Player would not function properly). ${ }^{55}$ The United States court required Microsoft to provide OEMs and end users the means to remove access (including icons) to the Windows Media Player application or to disable automatic launches. ${ }^{56}$

The effectiveness of this remedy was limited as only few OEMs took advantage of the opportunity to provide alternatives to Windows Media Player. ${ }^{57}$ One could, however, argue that taking into account the liability claim, which forced OEMs to carry Internet Explorer because they

${ }^{53}$ See United States v. Microsoft Corp., 231 F. Supp. 2d 144, 161 (D.D.C. 2002) (reporting on remand that the government dropped the tying charge after the D.C. Circuit remanded for further proceedings on that issue).

${ }^{54}$ However, bundling was also of concern in the maintenance of monopoly claim. See United States v. Microsoft Corp., 253 F.3d 34, 65 (D.C. Cir. 2001).

${ }^{55}$ See E.U. Microsoft I, supra note 2, II 798 (citing United States v. Microsoft, 231 F. Supp. 2d at $181 \mathrm{n} .23$ ); see also State of New York v. Microsoft Corp., 224 F. Supp. 2d 76, 308 (D.D.C. 2002) ("Likewise, the definition of Windows Operating System Product in the SRPFJ cannot curtail the ability of a court to determine that Microsoft has illegally tied two products which are separate under the antitrust laws."). For a discussion on the add/remove utility for middleware, see State of New York v. Microsoft Corp., 224 F. Supp. 2d at 202. Notably, Windows Media Player was included in the list of Microsoft middleware products by the Court. Id. at 193.

${ }^{56}$ State of New York v. Microsoft Corp., 224 F. Supp. 2d at 153-55.

57 William H. Page \& John E. LopatKa, The Microsoft Case 215 (2007). 
could not exclusively promote other browsers, the remedy was fully "successful" in providing them with that option. The fact that they may choose not to take advantage of that right does not necessarily mean the remedy was unsuccessful, unless a "successful" remedy is defined as a socially desirable market outcome, which could blur the distinction between competition law intervention and regulatory alternatives. The low utilization rate can be explained by the fact that unlike Judge Jackson's remedial order, the final consent decree did not require Microsoft to charge a lower license fee to OEMs that deleted access to Microsoft middleware. ${ }^{58}$ In addition, the Commission may have found this remedy inadequate "because it reinforced the applications barrier to entry from which Microsoft benefited by encouraging content providers to encode their products in Microsoft's standards." ${ }^{\text {99 }}$

The Commission imposed a more intrusive remedy on Microsoft than had been imposed in the United States case for two reasons. First, the importance of the leveraging argument and network effects in the European case and second, the Commission's insistence that freedom of choice needed to be restored to consumers that were coerced by Microsoft's conduct to use Windows Media Player as a default media player. The Commission concluded that there was coercion in spite of the fact that (1) Windows Media Player was offered for free, (2) there were other ways to reach consumers for competing products, and (3) the consumers were not forced but simply likely to use Windows Media Player. The extent of the competition problem was of a structural nature: the ubiquity of Windows undermined competition in media players because of network effects. ${ }^{60}$

${ }^{58}$ Id. at $215-16$.

59 Id. at 218.

${ }^{60}$ E.U. Microsoft I, supra note 2, II 979 (“Through tying with Windows, Microsoft uses Windows as a distribution channel to anti-competitively ensure for itself a significant competition advantage in the media player market. Competitors, due to Microsoft's tying, are a priori at a disadvantage irrespective of whether their products are potentially more attractive on the merits."). 
This structural problem deterred innovation and reduced consumer choice as competing media players that consumers could have preferred were excluded from the market. ${ }^{61}$

Thus Microsoft's distributional advantage led to a more intrusive competition law remedy than in the United States case, a remedy which affected Microsoft's freedom to design its products. Article 6 of the Decision required Microsoft to offer a version of Windows for client PC which did not include Windows Media Player media files but was otherwise equally performing. ${ }^{62}$ The remedy applied to licenses for both end-users and OEMs. Microsoft was also ordered to refrain from using "any technological, commercial, contractual or any other means which would have the equivalent effect of tying Windows Media Player to Windows," for example by selling the new version at a higher price than the Windows-with-Windows-Media-Player version. ${ }^{63}$ This did not oblige Microsoft to charge less for the Windows-without-Windows-Media-Player version than for Windows with Windows Media Player, since most competing media players were offered for free.

In addition, the Decision indicated which activities Microsoft could not engage in because those activities had an effect equivalent to tying. For example, Microsoft could not create privileged interoperability between Windows Media Player and Windows or any other favorable treatment to Windows, offer conditional discounts, punish or threaten OEMs who obtained Windows without Windows Media Player, or tie Windows Media Player to other products that "would exhibit a similar ubiquity as Windows," such as Microsoft Office. ${ }^{64}$ The Commission rejected Microsoft's arguments that removing the Windows Media Player would

61 Id. III 978-84.

62 Id. II 1019 ("These files contain the technologies which have been identified as bringing about the foreclosure effect by virtue of Windows Media Player being tied to Windows, namely the files that support the proprietary Microsoft codecs, file formats and DRM formats and the WMP user interface.").

${ }^{63}$ Id. II 1012.

${ }^{64}$ Id. II 1013(v). 
undermine the integrity of the operating system, because any interdependencies between the two products were the result of "deliberate choice by Microsoft" 55 and the integration of Windows Media Player was not a precondition for the multimedia capabilities of Windows. ${ }^{66}$ Microsoft was given 90 days to implement the remedy. The Commission rejected Microsoft's proposal to include other media players in Windows (the "must carry" remedy).

Measured in terms of the number of sales for the Windows XP N edition, the remedy was ineffective. The Commission's hope of widespread adoption of Windows XP N and the emergence of new powerful competitors did not materialize. ${ }^{67}$ One could compare the situation of the media player market with that of Internet browser market, which was the subject of the United States Microsoft case. ${ }^{68}$ As previously explained, after the Court of Appeals' judgment, the tying case was dropped. By the time of the Court of Appeals' decision, Microsoft commanded an impressive share of the Internet browser market (almost ninety percent). It is only recently that Mozilla Firefox, a competing Internet browser developed by Netscape in the form of open source software in 2004 after Netscape's defeat in the first browser war, ${ }^{69}$ has been able to challenge Internet Explorer's dominant position, with Internet Explorer's usage share

${ }^{65}$ Id. II 1027.

${ }^{66}$ Id. II 1031 ("Any efficiency implications of code removal would weigh heavier if Microsoft had shown that the integration of WMP was a precondition for these efficiencies. Microsoft has not provided evidence to that effect."). The Commission distinguished between two sorts of dependencies: "technical dependencies which would by definition lead to the non-functioning of the operating system and functional dependencies which can be dealt with 'gracefully.'" Id. II 1033.

${ }^{67}$ There is no doubt that powerful competition existed in Media Players before the introduction of Windows-N, as evidenced by the huge successes of the iPod and the associated media format, as well as the Adobe Flash media player.

68 United States v. Microsoft Corp., 253 F.3d 34 (D.C. Cir. 2001).

69 See Paul Boutin, Are the Browsers Wars Back?, Slate, June 30, 2004, http://slate.msn.com/id/2103152. 
reduced to $66.1 \%$ in the second quarter of $2009 .{ }^{70}$ The situation is different in the media player market, where a number of competing programs have developed during the same period. One of the reasons for the faster development of competing products in the media player market than in the internet browser market might also be the constraint and distraction that litigation in Europe placed on Microsoft's management and the effect the decision had on Microsoft's aggressive competitive ethos. ${ }^{71}$

\section{B. Substitutionary Remedies}

Substitutionary remedies may take different forms. For example, fines, damages, or disgorgement of illegally acquired gains. Like remedies in kind, substitutionary

70 See Microsoft Internet Explorer on Pace to Drop Below 50\% Market Share by May 2011, MACDAILYNEws, May 7, 2009, http://macdaily news.com/index.php/weblog/comments/21061 (stating that Mozilla Firefox had $22.47 \%$ of usage share). According to other reports, the Internet Explorer versions had a total of $54.4 \%$ market share in July 2009, a significant decline from 65.8\% in March 2009. See Erick Schonfeld, Since March, Internet Explorer Lost 11.4 Percent Share to Firefox, Safari, and Chrome, TECHCRUNCH, July 5, 2009, http://www.techcrunch.com/2009/07/ 05/since-march-internet-explorer-lost-114-percent-share-to-firefox-safari-a nd-chrome. Apple Safari 4 and Google Chrome have done well since their releases as well. In December 2009, Chrome surpassed Safari. The distribution of market share for browsers in December 2009 was: Internet Explorer 62.69\%, Firefox 24.63\%, Chrome 4.63\%, Safari 4.46\%, and Opera 2.31\%. Emil Protalinski, Chrome Grabs Market Share from IE and Firefox, Passes Safari, ARs TECHNICA, Jan. 4, 2010, http://arstechnica.com/ software/news/2010/01/chrome-grabs-market-share-from-ie-and-firefox-pas ses-safari.ars.

71 See generally Gary L. Reback, Free the Market! Why ONLy Government CAN Keep the Marketplace Competitive 24-49 (2009); William E. Kovacic, Designing Antitrust Remedies for Dominant Firm Misconduct, 31 CONN. L. REV. 1285, 1288-92 (1999) (advancing the hypothesis that the existence of an antitrust lawsuit may inhibit aggressive commercial behavior by the defendant as well as distract the defendant's employees from more productive functions, thus imposing formidable costs on the company). Nevertheless, Microsoft continued to introduce new products in the market, such as Zune (media player hardware) and Silverlight (for Internet media playback, like Adobe Flash) despite the antitrust action. 
remedies are designed to return the plaintiff or the protected category of right holders to the situation that would have existed absent the infringement. This is achieved through compensation of the right holders and/or by restoring competition. For example, the objective of fines is to raise the costs of the violation of competition law and therefore deter similar conduct in the future by both the company receiving the fine and third parties.

There are two forms of monetary transfers that can be used as substitutionary remedies. They may take the form of fines, which are a monetary transfer to the taxpayer, or damages, which are a monetary transfer to the "victims" of the anticompetitive practice. In either case, setting an optimal level for civil sanctions and damages should take into account the interaction of these two forms of substitutionary remedies. The European Commission imposed a fine on Microsoft that appeared at first sight to be quite large. However, the fine is small compared to the total amount of damages claims and settlements in the United States. Possibly, the amount of fines imposed in the European Microsoft case could lead to lower deterrent effects than the United States substitutionary remedies.

\section{Fines}

Article 3 of the Commission's decision imposed on Microsoft what appeared at the time to be a record fine in an abuse of dominance case. ${ }^{72}$ The Commission calculated the amount of the fines according to the method set in the Guidelines on the Method of Setting Fines. ${ }^{73}$ This included two steps: (1) setting the basic amount of the fine by reference to the proportion of the value of sales and the degree of gravity of the infringement, multiplied by the

72 The current record is the fine recently levied upon Intel by the Commission. See Case COMP/C-3/37.990 Intel, Commission Decision of 13 May 2009 (imposing a $€ 1.06$ billion fine upon Intel).

${ }^{73}$ See generally Commission Guidelines on the Method of Setting Fines Imposed Pursuant to Art. 23(2)(a) of Reg. No. 1/2003, 2006 O.J. (C 210) 2 [hereinafter Guidelines]. 
number of years of infringement; (2) adjusting that basic amount upwards or downwards taking into account a list of aggravating or mitigating circumstances. ${ }^{74}$ The fine reflected the gravity of Microsoft's infringement, a leveraging strategy which comprised two separate abuses: a refusal to supply and a tying abuse. ${ }^{75}$ The fact that Microsoft had already achieved a dominant or leading position in these industries was found a sufficient indication of the gravity of the infringement. The initial amount for the gravity of the infringement was set to €162,732,101, without distinguishing which amount represented the fine for the refusal to supply interoperability infringement and which one for the tying infringement. ${ }^{76}$ This starting amount was doubled to ensure "a sufficient deterrent effect on Microsoft," in light of the firm's significant economic capacity. ${ }^{77}$ The Commission found that the duration of the infringement was also particularly long: the refusal to supply abuse lasted six years and it was still ongoing at the time of the decision; the tying abuse lasted more than 5 years. Thus the Commission increased the basic amount of the fine by fifty percent to $€ 497,196,204$, taking into account an increase of ten percent for each year of participation in the infringement. As the General Court noted in its decision, the fine represented 7.5\% of Microsoft's turnover in the market for client PC and work-group server operating systems in Europe, ${ }^{78}$ below the ten percent threshold set by the European Commission's Guidelines on the method of setting fines. ${ }^{79}$ No aggravating or attenuating circumstances were found.

74 Id. II 20 ("The assessment of gravity will be made on a case-by-case basis for all types of infringement, taking account of all the relevant circumstances of the case").

75 E.U. Microsoft I, supra note 2, III 1061-68.

76 Id. II 1075.

77 Id. II 1076 (increasing the fine to $€ 331,464,203$ ).

78 Case T-201/04, Microsoft Corp. v. Commission, 2007 E.C.R. II-3601, II 1319.

79 See Guidelines, supra note 73, II 32 ("The final amount of the fine shall not, in any event, exceed $10 \%$ of the total turnover in the preceding business year of the undertaking or association of undertakings participating in the infringement"). 
The General Court affirmed the fine imposed by the Commission and rejected Microsoft's arguments that no fine should be imposed because the infringements resulted from "novel theories of law" ${ }^{80}$ or that Microsoft had already taken measures, following the United States settlement, to provide the necessary degree of interoperability. ${ }^{81}$ The Court found that the doubling of the basic amount of the fine by the Commission was justified for deterrence reasons: in a prescient (given recent developments) paragraph the Court noted that "since Microsoft is very likely to maintain its dominant position on the client PC operating systems market, at least over the coming years, it cannot be precluded that it will have other opportunities to use leveraging vis-a-vis other adjacent markets." ${ }^{82}$

Although the fine imposed on Microsoft seems particularly imposing, its deterrent effect is questionable. In the high technology sector, where network effects may tip the market for some time towards a particular technological standard, incurring the costs of civil penalties may still be a profitable strategy for monopolists where civil penalties are not set at a level that fully internalizes the dominant firm's gains (past and future) from the antitrust violation. ${ }^{83}$ The effectiveness of this part of the European remedy should be examined in comparison to the pecuniary sanctions imposed

${ }^{80}$ Case T-201/04, Microsoft Corp. v. Commission, II 1299.

${ }^{81}$ Id. II 1227.

${ }^{82}$ Id. II 1363.

${ }^{83}$ See William M. Landes, Optimal Sanctions for Antitrust Violations, 50 U. CHI. L. REV. 652, 656-57 (1983) (showing that violation of antitrust laws may be efficient for the infringer when the gains to the infringer following the violation exceed the sanctions imposed multiplied by the likelihood of apprehension and conviction). Here, the amount of the fine imposed for an antitrust violation is based on an accounting of gains as defined and measured at the time of the decision and is, in any case, limited to ten percent of the firm's worldwide turnover. This amount will not necessarily include all future gains arising from the exclusion or marginalization of competitors and the maintenance of the monopolistic position in the future. These gains may be particularly important in high technology markets where network effects can erect barriers to entry leading to entrenched dominant positions for a long period of time. 
in the United States Microsoft case. There is no provision for civil penalties, such as fines, under the Sherman Act. ${ }^{84}$ In United States antitrust law, pecuniary sanctions take the form of wealth transfers to the victims of the exclusionary practice, which may engage a private action to collect damages. ${ }^{85}$ Most often, this leads to settlements entered between the monopolist and the claimants. ${ }^{86}$

The next section will discuss the availability of damages and settlements as an effective "pecuniary" remedy. These remedies provide compensation/restitution to the victims of the competition law infringement, as well as deter the monopolist or dominant firm from adopting similar practices in the future by acting indirectly on their incentives.

\section{Damages}

In comparison to the amount of the fines imposed by the European Commission, the monetary transfers to consumers and competitors affected by Microsoft's antitrust law infringement in the United States case seem particularly important. According to Harry First, more than 220 private cases have been filed against Microsoft by consumers and rivals. ${ }^{87}$ "Consumer class actions represent the largest group of claims (more than eighty percent), with individuals having filed thirty cases and state attorneys general having filed

84 A proposal to amend the law to permit the imposition of civil fines has been rejected recently by the Antitrust Modernization Commission. See Antitrust Modernization Comm'N, REPORT AND RECOMMENDATIONS 285-91 (2007), available at http://govinfo.library.unt.edu/amc/report_rec ommendation/amc_final_report.pdf. For critical analyses, see Harry First, The Case for Antitrust Civil Penalties 76 AnTITRUst L.J. 127 (2009); Stephen Calkins, Civil Monetary Remedies Available to Antitrust Enforcers, 40 U.S.F. L. REV. 567 (2006).

85 Clayton Act $\S 4,15$ U.S.C. $§ 15$ (2006).

${ }^{86}$ See Jeffrey M. Perloff, Daniel L. Rubinfeld \& Paul Ruud, Antitrust Settlements and Trial Outcomes, 78 REV. ECON. \& STAT. 401, 401-09 (1996).

${ }^{87}$ Harry First, Netscape is Dead: Remedy Lessons from the Microsoft Litigation 6 (N.Y.U. Law \& Econ. Research Paper No. 08-49, 2008), available at http://ssrn.com/abstract $=1260803$. 
two cases on behalf of their non-business citizens." 88 Individual private plaintiffs had an important hurdle to overcome, as they had to prove that they were overcharged as a result of Microsoft's maintenance of monopoly in the operating systems market. As indirect purchasers, they were barred from bringing a federal antitrust private damages claim, ${ }^{89}$ and class actions had to pass the procedure of class certification. ${ }^{90}$

Important difficulties also arose as to whether Microsoft overcharged by excluding potential competing platforms in the operating systems market. ${ }^{91}$ The question was what would have been the price of Windows had Netscape and Java been able to challenge Microsoft's dominant position and develop a competing platform. Judge Jackson's decision contained some indications that Microsoft was able to charge higher prices to Windows 98 upgrades, while lower prices would have also been profitable. However, Judge Jackson also recognized that it might be in Microsoft's interest to

88 Id.

${ }^{89}$ Illinois Brick Co. v. Illinois, 431 U.S. 720 (1977).

${ }^{90}$ See PAGE \& LOPATKA, supra note 57, at 235 (noting that the majority of the courts adopted a liberal standard for class certification).

${ }^{91}$ It remains unclear whether Netscape together with Java posed a real threat to Windows. Netscape's CEO Jim Barksdale completely dismissed that likelihood at trial, stating that Netscape with Java was no substitutes for Windows. See Transcript of Record at 72-75, United States v. Microsoft Corp., 84 F. Supp. 2d 9 (D.D.C. 1999) (Civ. No. 98-1232), available at http://cyber.law.harvard.edu/msdoj/transcripts/1020b.doc. However, internal Microsoft emails presented at trial show that Microsoft took this potential threat very seriously. See Plaintiff's Joint Proposed Finding of Facts II 54, United States v. Microsoft, 84 F. Supp. 2d 9 (D.D.C. 1999) (Civ. No. 98-1232), available at http://www.justice.gov/atr/cases/f260 0/2613-1.htm\#III (noting that Microsoft viewed Netscape Navigator as a threat to its operating system monopoly as it threatened to reduce the applications barrier to entry and to "commoditize" Windows, in the words of Bill Gates). But if Netscape's success was very unlikely in the absence of anticompetitive actions, the remedy should be limited to removing the anticompetitive hurdle, and should not extend to restructuring the market. 
"[keep] the price of Windows low today" in order to support the growth of the operating system market. ${ }^{92}$

Netscape/AOL and Sun, who brought the case against Microsoft in the E.U., also filed private damages suits in the United States. Netscape settled in 2003, while Sun settled a few days after the publication of the decision of the European Commission in 2004 and consequently retreated as a third party intervener in the European litigation..$^{93}$ As for other Microsoft opponents in the European antitrust case, both RealNetworks and Novell settled, with the exception of Novell's pending lawsuit against Microsoft relating to the damage suffered by WordPerfect for lack of interoperability information..$^{94}$ In total, the settlements in the United States exceeded $\$ 3.5$ billion. ${ }^{95}$

In comparison, the fine imposed by the European Commission, which represents only a fraction of the total amount of the settlements, seems to lead to underdeterrence. This conclusion is reinforced by the absence of any private action brought against Microsoft for damages in the E.U. There are two cumulative explanations for this: First, private enforcement of E.U. competition law is nascent and does not include a system of treble damages or other incentives for private actions. ${ }^{96}$ Second, the heart of the

${ }^{92}$ United States v. Microsoft Corp., 84 F. Supp. 2d 9, 27 (D.D.C. 1999). However, this argument is not credible given that Microsoft already had over ninety percent OS market share. In fact, it is likely that potential competition in the OS market drove Microsoft to charge a significantly lower price than the unconstrained monopoly price. See generally Nicholas Economides, The Microsoft Antitrust Case, 9 J. Indus., Competition \& TRADE 1, 7-39 (2001).

${ }_{93}$ Stephen Shankland, Sun Settles with Microsoft, Announces Layoffs, CNET NEwS, Apr. 2, 2004, http://news.cnet.com/Sun-settles-with-Microso $\mathrm{ft}$,-announces-layoffs/2100-1014_3-5183848.html.

${ }^{94}$ First, supra note 87, at 8-9.

${ }^{95}$ Id. at 27.

${ }^{96}$ See Commision of the European Communities, Commission White Paper on Damages Actions for Breach of the EC Antitrust Rules, COM (2008) 165 final (Apr. 2, 2008), available at http://eur-lex.europa.eu/ LexUriServ/LexUriServ.do?uri=COM:2008:0165:FIN:EN:PDF (discussing possible options). 
European case was not maintenance of monopoly, and therefore a possible overcharge of Windows, but the extension of the monopoly power of Microsoft to the work group server and media player markets.

Concerning the work group server market, it is not clear if consumer harm took a different form than just a slower pace of innovation (because of the exclusion of competitors), or also derived from an increase in the prices charged by Microsoft. In the media player market, the product was given for free, so the possible harm to consumers lay not in higher prices but in possibly lower quality, as allegedly better quality media players were excluded from the market. It would, however, be extremely difficult and costly to quantify this reduction of quality. ${ }^{97}$ Because of the limited access of European consumers to damages and the difficulties in winning damages in the United States because of comity concerns (in particular after Empagran ${ }^{98}$ ) European consumers will not be compensated and, consequently, there will be less deterrence. The weakness of private enforcement of competition law in Europe indicates that fines should be set at a higher level in order to ensure more effective deterrence. ${ }^{99}$

${ }_{97}$ However, during the infringement period there was significant innovation and entry of new products such as the iPod and the Adobe Flash Player.

98 F. Hoffmann-La Roche Ltd. v. Empagran S.A., 542 U.S. 155 (2004).

99 This supposes, however, a clarification of the liability standard under Article 102 TFEU. The European Commission has recently adopted guidance on its enforcement priorities. See Communication from the Commission: Guidance on the Commission's Enforcement Priorities in Applying Article 82 of the EC Treaty to Abusive Exclusionary Conduct by Dominant Undertakings, 2009 O.J. (C 45) 7. Note the guidance on enforcement priorities is a softer law instrument than guidelines; it is complementary to the Commission's specific enforcement decisions. Using guidance instead of guidelines offers the Commission more leeway in presenting its approach for Article 102. The Commission could not have adopted guidelines contrary to the rulings of the European courts. See Op. Advocate Gen., Case C-8/08, T-Mobile Netherlands BV v. Raad van bestuur van de Nederlandse Mededingingsautoriteit (Feb. 19, 2009), available at http://eur-lex.europa.eu/LexUriServ/LexUriServ.do?uri=CEL EX:62008C0008:EN:HTML. Finally, the Commission maintains the 


\section{DID THE E.U. MICROSOFT CASE REMEDIES}

\section{FAIL?}

The success of the interoperability remedy required a sustained and continuing effort of setting and monitoring compliance standards, which was particularly difficult in the absence of a regulatory authority that could supervise its enforcement. The European Commission initiated the mechanism of the Monitoring Trustee, which proved particularly useful in the promotion of the SAMBA-Microsoft settlement, the only positive outcome of the Commission's decision. However, the General Court annulled this part of the decision. The crafting of remedies needs to involve the consideration of an adequate institutional mechanism for their enforcement.

The design of the tying part remedy was also particularly problematic, as the Commission took a quasi-regulatory role by imposing upon Microsoft a particular product design which, however, produced very poor results in the marketplace. We will, however, argue that a structural remedy would not have been appropriate in this case. We will then examine some possible alternative remedies before addressing the important issue of the proportionality of the remedies.

\section{A. The Enforcement Difficulties of the Interoperability Remedy: Institutional Aspects}

The appointment of a Monitoring Trustee, independent from Microsoft but on its payroll, was the primary mechanism of enforcement for the remedy imposed by the Commission for both the interoperability and tying parts. ${ }^{100}$ The Monitoring Trustee was required to assess whether the information made available by Microsoft was complete and accurate and to ensure that Windows-N was not worse performing than any bundled version of Windows Microsoft

ability to reject a complaint when it considers that a case lacks priority for other reasons (e.g., lack of Community interest).

100 E.U. Microsoft I, supra note 2, II 1044-45. 
would continue to provide on the market. ${ }^{101}$ Furthermore, Article 4 of the European Commission's decision imposed on Microsoft an obligation to refrain from repeating any act or practice which would have the same or equivalent object or effect as the anticompetitive conduct. This exemplified the forward-looking role of the Monitoring Trustee, as it was clear that "the obligation to disclose interoperability information must apply 'in a prospective manner' to future generations of Microsoft's products."102 Microsoft successfully challenged this part of the decision at the General Court for lack of legal basis. ${ }^{103}$

The General Court found that Regulation 17/62, in force at the time of the decision, did not provide the Commission with "the authority to compel Microsoft to grant to an independent monitoring trustee powers which the Commission itself was not authorized to confer on a third party." ${ }^{04}$ The Court questioned the independence that the Monitoring Trustee would have had from both the Commission and Microsoft and the broad scope of his powers and mission. ${ }^{105}$ It also noted that no limit in time was envisaged for his continuing intervention in monitoring Microsoft's compliance. Moreover, the Court found that the costs associated with the enforcement of the remedy and compliance should not be borne by Microsoft but by the Commission in the course of fulfilling its own investigation and enforcement responsibilities. ${ }^{106}$

The conservatism showed by the Court in envisioning an effective compliance mechanism seems misplaced. The independence of the Monitoring Trustee from Microsoft and the Commission ensured its impartiality, which was an essential characteristic in order to enhance compliance and cooperation from Microsoft. This cooperation was crucial for

101 Id. II 1046.

102 Case T-210/04, Microsoft Corp. v. Commission, 2007 E.C.R. II-3601, II 1270 .

103 Id. II 1278.

104 Id. III $1271,1278$.

105 Id. II 1269.

106 Id. II 1277. 
the success of the remedy and the provision of adequate information on the specifications for protocols implemented in Windows work group server operating systems. After all, it is because the Monitoring Trustee had developed a relation of confidence with Microsoft's technical staff that he had been able to mediate successfully between Microsoft and SAMBA. Ironically, this success came during the period following the Court's decision and before the Commission formally replaced him with a system of ad hoc external experts. ${ }^{107}$ It may not have been possible to achieve the same degree of cooperation from Microsoft had the Commission employed internal or external experts for the enforcement of the decision, because no direct relationship would have existed between Microsoft's technical staff and the technical staff of the parties requiring interoperability. It is true that the Commission's decision should have included a realistic time horizon for the monitoring of the decision and should have quantified the costs. However, as became clear in the compliance procedure for the United States antitrust decision, the extent and time-horizon of monitoring was unknown and depended on (1) the government clearly articulating its goals and (2) Microsoft's willingness and ability to provide detailed specifications for its interoperability information. ${ }^{108}$ Sharing the costs of the enforcement mechanism would have limited the exorbitant, seemingly disproportionate costs for Microsoft, but at the same time it would have slightly reduced Microsoft's incentives to comply with the decision. The Commission could have nevertheless taken on a larger proportion of the expenses during the initial stages of the operation of the enforcement mechanism, with Microsoft's share progressively increasing over time so that they bore the costs of delayed compliance.

The appointment of the Monitoring Trustee illustrates the blurring of the distinction between competition law and

107 Page \& Childers, supra note 48, at 346.

108 Id. at 75 (noting that "we have no way of estimating the costs of a program of this scale with any accuracy, but they certainly run into eight figures"). 
regulation when it comes to the enforcement of far-reaching and forward-looking remedies, with regard to both the scope of the obligations imposed and the time-horizon of the remedy. The European Monitoring Trustee intervened three years after the Technical Committee in the United States antitrust case started to monitor Microsoft's compliance. The United States Technical Committee had become, at that time, a quasi-regulatory entity employing forty experts, and it had the ability to persuade the Department of Justice and the state Attorneys General that had sued Microsoft that additional obligations and burdens should be imposed to ensure effective interoperability. The Technical Committee could receive complaints, interview Microsoft's staff, and examine the Windows source code, subject to confidentiality. The expenses and salaries of the Committee were assumed by Microsoft. ${ }^{109}$ The Monitoring Trustee was able to build on these efforts to ensure interoperability and to benefit from the United States' experience. He also contributed to the compliance effort in the United States. Indeed, in 2006, the United States Technical Committee started working closely with Microsoft's experts to improve the technical documentation provided to licensees, using "as a starting point the specification agreed upon between Microsoft and the European Commission's Monitoring Trustee."110

One could envision a higher degree of cooperation at the remedial stage of multijurisdictional cases such as Microsoft if compliance is ensured by an independent entity, like a Monitoring Trustee or a Technical Committee, and costs of the compliance mechanism are shared between jurisdictions. It is clear that despite the different theories of antitrust liability in Europe and in the United States, in the end, the remedies imposed with regard to the interoperability part of the decision converged. This type of international cooperation at the remedial stage of antitrust cases could be

109 State of New York v. Microsoft Corp., 224 F. Supp. 2d 76, 273-74 (D.D.C. 2002).

110 Joint Status Report on Microsoft's Compliance with the Final Judgments, United States v. Microsoft Corp., 2006 WL 5154418 (D.D.C. Aug. 30. 2006) (Civ. Nos. 98-1232, 98-1233). 
enhanced if the Commission had the ability to appoint independent compliance officers/experts. The procedure has been used in the context of Article 9 of Regulation 1/2003 commitment decisions, such as the Deutsche Bundesliga ${ }^{111}$ and FA Premier League ${ }^{112}$ cases concerning the collective selling of media rights to football matches, where the Commission appointed a monitoring trustee to monitor the auctions of the Premier League rights, or in Repsol, ${ }^{113}$ where the Monitoring Trustee monitored the opening up of the fuel distribution system in Spain. Monitoring Trustees were also used in merger cases cleared with obligations and commitments. In those cases the Trustees may enjoy significant powers, such as the supervision and management of the divested business, the exercise of shareholder rights or the appointment of board members. ${ }^{114}$ The General Court's decision in Microsoft raises questions on the legality of this practice, particularly since the company giving the commitment is usually required to incur the Trustee's costs. Regulation 1/2003 does not grant the Commission any power to establish such monitoring mechanisms. This is an issue that has not been tackled in the latest European Commission's Report on the functioning of Regulation $1 / 2003 .{ }^{115}$

111 Case COMP/C-2/37.214 German Bundesliga, Commission Decision of 19 Jan. 2005 (summary at 2005 O.J. (L 134) 46).

112 Commission Notice Published Pursuant to Article 19(3) of Council Regulation No. 17 Concerning Case COMP/C.2/38.173 and 38.453-Joint Selling of the Media Rights of the FA Premier League on an Exclusive Basis, 2004 O.J. (C 115) 3.

113 Case COMP/B-1/38.348 Repsol CPP, Commission Decision of 12 Apr. 2006 (summary at 2006 O.J. (L 176) 104).

114 See, e.g., Case COMP/M.5406 IPIC/Man Ferrostaal AG, Commission Decision of 19 May 2009 (summary at 2009 O.J. (C 114) 08); Case COMP/M.5253 Sanofi-Aventis/Zentiva, Commission Decision of 20 Mar. 2009 (summary at 2009 O.J. (C 66) 24); Case COMP/M.5224 EDF/British Energy, Commission Decision of 11 Nov. 2008 (summary at 2008 O.J. (C 288) 10); Commission Notice on Remedies Acceptable under Council Regulation 139/2004 and under Regulation 802/2004, 2008 O.J. (C 267) 1.

115 Communication from the Commission to the European Parliament and the Council, Report on the Functioning of Regulation 1/2003, COM 


\section{B. The "Failure" of the Windows-N Remedy and the New Choicescreen Remedy}

As discussed previously, the E.U. decision, which was upheld by the Court of First Instance, found Microsoft liable for tying Windows Media Player with Windows. ${ }^{116}$ Windows Media Player participates in a market where it and its substitute media players are distributed without charge. Since there are always costs associated with developing software, both Microsoft and its competitors sell their media players below production and distribution cost. Of course, as part of Windows, Windows Media Player is subsidized by part of the Windows revenue.

Companies such as Microsoft and its competitors (for example RealAudio) distribute their media players for free with the hope that their software development costs will be recouped if (1) in the future the product will be sold at a positive price, (2) the firm will be able to sell upgraded versions of the software (with more features) at a positive price, or (3) the firm will be able to sell products or services complementary to the free product (for example, sell music or video downloads at a positive price or sell software that produces audio or video in a compatible format). Although media players have been distributed for free for almost a decade and have experienced significant technological advances, there is no evidence that their basic versions will ever be sold at a positive price. Additionally, with the exception of Apple's iTunes, there is no evidence of substantial revenues from sales of complementary products. ${ }^{117}$ Additionally, iTunes profits come almost exclusively from sales of the complementary hardware

(2009) 206 final (Apr. 29, 2009), available at http://eur-lex.europa.eu/ LexUriServ/LexUriServ.do?uri=CELEX:52009DC0206:EN:NOT.

116 See supra Part III.A.2.

117 Of course, there are attempts to get revenue from complementary goods. For example, Real Networks charges for an upgraded version of its media player and offers content through subscription services. However, these revenues are not substantial and have led to the decline of companies that are essentially only in the software media player business such as Real Networks. 
(iPods). ${ }^{118}$ Thus, restriction of competition in the media player universe can cause no damages arising from higher prices, since no company ever charges a positive price. The only possible damages can arise from a restriction of the full extent of varieties and qualities of media players that might be available in the absence of the tying behavior of Microsoft.

The variety issue is further complicated by the fact that a number of companies distribute media players that have a "favored" format but can also play content in a number of other formats, to the extent that the other format owners allow it. So, for example, Windows Media Player plays WMA (the Microsoft-favored format) as well as MP3 (based on a public standard) but does not play the RealAudio format because the RealAudio specifications have not been made public. Similarly, RealAudio plays its proprietary format, as well as WMA, MP3, and others. Thus, wide distribution of Windows Media Player does not necessarily imply dominance of the WMA format since Windows Media Player can play many formats.

It is possible, however, that even when content providers engage in dual encoding (encoding in a number of different formats), Microsoft may still benefit from its distributional advantage. Ian Ayres and Barry Nalebuff noted that "Microsoft would still have the unique ability to ensure that its media player would be on all new machines-and thus eventually on all machines" and that "in turn, would mean that a content provider that encoded its content in the Windows Media Player format would be ensured nearly $100 \%$ reach in the market" and would have therefore little incentive to engage in dual encoding. ${ }^{119}$ The conclusion that Windows Media Player will be eventually on all PCs is true only under restrictive modeling assumptions, and empirical

118 See, e.g., Liam Cassidy, More on Apple's Billions: This Time, It's iTunes, THEAPPLEBLOG, Feb. 25, 2010, http://theappleblog.com/2010/02 /25/more-on-apples-billions-this-time-its-itunes/.

119 See Ian Ayres \& Barry Nalebuff, Going Soft on Microsoft? The EU's Antitrust Case and Remedy, 2 Economists' VoICE 1, 5 (2005), http://www. bepress.com/cgi/viewcontent.cgi?article $=1045 \&$ context $=e v$. 
evidence attests that it is certainly not true today. ${ }^{120}$ Additionally, the fact that Windows Media Player plays a number of other formats, including some based on open standards, makes the exclusivity argument of including Windows Media Player with Windows weak.

In the aftermath of the United States $v$. Microsoft Corporation settlement, ${ }^{121}$ any consumer as well as any computer manufacturer can set up any media player as the default one, thereby severely limiting any distributional advantage of the joint distribution of Windows Media Player with Windows. However, consumers and computer manufacturers do not benefit from the same distributional opportunities than Windows Media Player, precisely because dual encoding may not be materially equivalent to ubiquitous encoding.

Finally, the distribution advantage that any player enjoys arguably is limited because any rival media player can be downloaded and installed in a few minutes. If consumers do not think it is worth spending a couple of minutes to download and install rival players, clearly consumers do not see significant value in the variety and quality that rival players may add. Thus, the damages that can be ascertained from Microsoft's distributional advantage cannot be substantial. The Commission and the Court may have overestimated the distributional advantage conferred to Windows Media Player by its joint distribution with Windows.

120 See WebsiteOptimization.com, iTunes Player Hits a High Note, Passes RealPlayer, http://www.websiteoptimization.com/bw/0801/ (last visited Apr. 8, 2010).

121 United States v. Microsoft Corp., 215 F. Supp. 2d 1 (D.D.C. 2002) (finding that the Tunney Act requiring judicial determination of whether the consent decree was in the public interest was applicable); United States v. Microsoft Corp., 231 F. Supp 2d. 144 (D.D.C. 2002) (considering that the decree's remedy provisions were in the public interest); State of New York v. Microsoft Corp., 224 F.Supp.2d 76 (D.D.C. 2002) (finding that the remedy imposed by the consent decree was appropriate for the non-settled states remedy proposal); aff'd sub nom. Massachusetts v. Microsoft Corp., 373 F.3d 1199 (D.C. Cir. 2004). 
As a remedy, the Commission forced Microsoft to produce and distribute in the E.U. a version of Windows without Windows Media Player, which became known as WindowsN. ${ }^{122}$ The Commission allowed Microsoft to continue producing and distributing the U.S. version of Windows that included Windows Media Player (but was subject to the requirements of the consent decree that resolved United States $v$. Microsoft Corporation) in the E.U. ${ }^{123}$ The E.U. did not mandate a specific price difference between Windows and Windows-N. ${ }^{124}$ The two versions of Windows were sold in the E.U. at the same price and practically no OEM bought and adopted Windows-N. ${ }^{125}$ Thus, the remedy imposed by the Commission had no noticeable effect in the marketplace. At the same time, the dire predictions of expanded dominance of WMA never materialized in the long period between the beginning of the E.U. case and the Commission's decision or even later. In contrast, a new, until recently proprietary, format promoted by Apple (tied to

${ }^{122}$ See E.U. Microsoft I, supra note 2, II 1010 ("Under this Decision, Microsoft will have to offer a version of Windows for client PCs which does not include Windows Media Player.”).

${ }^{123}$ Id. II 1021.

124 The lack of a price difference requirement is in sharp contrast with the proposal to the District Court by the nine states ("litigating states") that did not agree with the Department of Justice-Microsoft settlement that was also signed by nine other states. The litigating states proposed to "freeze Windows" to its pre-1998 state and impose on Microsoft the requirement to sell any additional functionality at an additional price. It is interesting, however, that the General Court noted in its decision that "[s]hould Microsoft now decide to sell the unbundled version of Windows at the same price as the bundled version, the Commission would examine that price by reference to the present market situation and in the light of Microsoft's obligations to refrain from any measure having an equivalent effect to tying and, if necessary, adopt a new decision pursuant to Art. 82 EC." Case T-201/04, Microsoft Corp. v. Commission, 2007 E.C.R. II-3601, II 908.

125 Windows-N sold less than 2000 copies. See Press Release, Microsoft Corp., Microsoft Fact Sheet: Windows XP N Sales (Apr. 2006), http://www.microsoft.com/presspass/legal/european/04-24-06windowsxpns alesfs.mspx/ ("[O]nly 1,787 copies of Windows XP $\mathrm{N}$ have been sold to retailers and distributors in Europe.”). 
hardware also produced by Apple) has become the dominant format in the market for song downloads, a key market for goods that are complementary to media players. Additionally, "Flash player," a new player from Adobe, has become the standard video player in Internet browsers.

We are at a loss to understand why the E.U. Commission thought that requiring Microsoft to produce and distribute Windows without Windows Media Player was going to significantly increase competition in media players. It was almost mathematically certain that Windows-N (without Windows Media Player), sold at the same price as Windows (with Windows Media Player), would not sell well, and therefore would have little impact on the market share of Windows Media Player. It is also hard to imagine how depriving consumers of Windows Media Player in Windows$\mathrm{N}$ in the post-United States-settlement environment, where both the OEM and the final consumer could designate any media player as the default one, would have enhanced consumers' choice. The European Commission rather considered that consumers expected a media player but advanced that the OEMs should be free to build PCs that feature a non-Microsoft media player. ${ }^{126}$

In negotiations before the Commission's decision was announced, the Commission rejected a reported Microsoft proposed remedy to include three rival media players besides Windows Media Player with Windows and to let the consumer designate the default player. ${ }^{127}$ This proposal would have guaranteed as wide a distribution of RealAudio and other players as Windows Media Player, would have erased any distributional advantage of Windows Media Player, would have dispelled any tying concerns, and would have given full decision power to consumers. Such a remedy would have addressed the competition law concerns raised by Microsoft's abuse much more effectively than the

${ }^{126}$ E.U. Microsoft I, supra note 2, II 1025.

${ }^{127}$ See Tobias Buck, When Microsoft and Brussels Went Separate Ways, Fin. TIMES, Apr. 21, 2006, at 13, available at http://www.ft.com/cms/ s/2/51bd683e-d098-11da-b160-0000779e2340.html. 
proposed remedy. ${ }^{128}$ At the same time, its adoption would have at least guaranteed the ability of even a dominant firm (Microsoft) in the complementary good (Windows) to innovate and distribute in the way it finds most appropriate. The benefits of this proposal both for consumers and innovation are obvious and substantial in comparison to the imposed remedy. It provides consumers the best of both worlds-the benefits of standalone media players and the benefits of an integrated solution.

We argue that the requirement that a dominant firm "must carry" the competitors products should, however, only be imposed when (1) there are substantial distributional advantages of the dominant firm in the sense that access to the dominant firm's input is indispensable in order to viably stay on the market, and (2) there are substantial consumer losses arising from the lack of distribution through the dominant firm. Because of the United States $v$. Microsoft Corporation settlement, computer manufacturers can install any media player they want without facing any penalties or retaliation from Microsoft. To the extent that computer manufacturers install what consumers desire, the present extent of distribution of Windows Media Player with Windows seems more than a reflection of consumers' choice than a decision by Microsoft. Of course consumers are likely to be better off if they receive more free software delivered with their new computer, thus avoiding search costs and reducing the risk of the status quo bias advantages that benefit software that is already downloaded on the

128 Indeed, the issue in this case was "not that Microsoft integrates [WMP] in Windows, but that it offers on the market only a version of Windows in which [WMP] is integrated, that is to say, that it does not allow OEMs or consumers to obtain Windows without [WMP] or, at least, to remove [WMP] from the system consisting of Windows and [WMP]." Case T-201/04, Microsoft Corp. v. Commission, 2007 E.C.R. II-3601, II 1149. The remedy could have identified a number of media players from those existing at the time of the commitment of the abuse that would have been integrated to Windows. It is in this respect different from a common carrier obligation, as it would not necessarily have extended to media players that would have been commercialized after the termination of the abuse. 
desktop. ${ }^{129}$ This, however, does not mean that the dominant firm should have the obligation to distribute this software, and additionally to do so without collecting practically any revenue from competitors whose software it is forced to distribute, unless the operating system is considered as an essential facility. ${ }^{130}$ But in this case the standards of liability are different (allegedly stricter) than those required for

129 William Samuelson \& Richard J. Zeckhauser, Status Quo Bias in Decision Making, 1 J. RISK \& UnCERTAINTY 7, 7 (1988); see also Amos Tversky \& Daniel Kahneman, The Framing of Decisions and the Psychology of Choice, 211 SCI. 453 (1981) (discussing the dependence of preferences on the formulation of decision problems and the way choices are framed).

${ }^{130}$ The European Commission has defined an essential facility as "a facility or infrastructure without access to which competitors cannot provide services to their customers." See Case IV/34.174, B\&I Line PLC v. Sealink Harbours Ltd., 5 C.M.L.R. 255, II 41 (1992) (stating that the European Commission has defined an essential facility as "a facility or infrastructure without access to which competitors cannot provide services to their customers"). Advocate General Francis Jacobs noted in his opinion in Case C-7/97, Oscar Bronner GmbH \& Co. KG v. Mediaprint, 1998 E.C.R. I-7791, II 61, that "refusal of access may in some cases entail elimination or substantial reduction of competition to the detriment of consumers in both the short and long term" and "[t]hat will be so where access to a facility is a precondition for competition on a related market for goods or services for which there is a limited degree of interchangeability." See Alexandros Stratakis, Comparative Analysis of the US and EU Approach and Enforcement of the Essential Facilities Doctrine, 27 EuR. COMPETITION L. REV. 434 (2006) (comparing the scope of the essential facilities doctrine in Europe and in US antitrust law); John Temple Lang, Defining Legitimate Competition: Companies' Duty to Supply Competitors and Access to Essential Facilities, 18 FordHAM INT'L L.J. 439, 446 (1994) (stating that the essential facilities doctrine has been merged with the general category of cases involving refusal to supply); see also Communication from the Commission: Guidance on the Commission's Enforcement Priorities in Applying Article 82 EC to Abusive Exclusionary Conduct by Dominant Undertakings, 2009 O.J. (C45) 7, II 78 (noting that the concept of refusal to supply covers a broad range of practices, such as a refusal to supply products to existing or new customers, refusal to license intellectual property rights, including when the licence is necessary to provide interface information, or refusal to grant access to an essential facility or a network). 
tying. ${ }^{131}$ It seems to us that, if the competition authority decides to impose a "must carry" remedy, it should bring a proper essential facilities case rather than rely on the most favorable, for carrying its standard of proof, liability standards of tying and then ask for a "must carry" remedy.

The "must carry" obligation is of special interest because it has been considered by the E.U. as a possible remedy in its current investigation of Microsoft for bundling Internet Explorer with Windows, as discussed in detail below. ${ }^{132}$ Clearly, the E.U. could not require that Windows be distributed without an Internet browser and the ability to download a browser because that would severely cripple the ability of the typical user to reach the Internet. But does it make sense for Microsoft to be required to distribute rival browsers?

It may be that requiring Microsoft to distribute rival browsers may not provide an appropriate remedy, in the presence of weak anticipative effects. Like with media

131 The European Court of Justice took a restrictive view of the obligation of a dominant undertaking to grant access to its facilities by imposing a number of conditions in Case C-7/97, Oscar Bronner GmbH \& Co. KG v. Mediaprint, 1998 E.C.R. I-7791, III 41, 45-46. The refusal "must be likely to eliminate all competition" on the part of the competitor requesting access, that access should be indispensable and not only make it harder for the requesting undertaking to compete and it should not be capable of being objectively justified. With regard to the indispensability condition, the Court held that access would have been indispensable only if it was not economically viable to create a home-delivery system for a newspaper with a comparable circulation to the dominant firm's. The conditions in Bronner set the outer boundaries of the special responsibility of a dominant firm and consequently of the corresponding duty, under Article 102 , to abstain from any action that would be likely to exclude rivals from the market. The excluded rival would be granted access only if it is impossible for an undertaking with a comparable output to the dominant firm to develop such facility, which indicates that the Court applies a not yet as efficient as test. For a comparison with tying standards, see Economides \& Lianos, supra note 8, at 539-40.

132 Press Release, Eur. Comm'n, Antitrust: Commission Initiates Formal Investigations Against Microsoft in Two Cases of Suspected Abuse of Dominant Market Position (Jan. 14, 2008), available at http://europa. $\mathrm{eu} / \mathrm{rapid} /$ pressReleasesAction.do?reference=MEMO/08/19 (awaiting the publication of the final decision of the Commission). 
players, competing browsers can be downloaded and installed in a few minutes, so the reluctance of consumers to do so might show that they do not find any competing browser to be sufficiently desirable. But consumers' unwillingness to download other browsers may reflect a status quo bias favoring Internet Explorer, particularly because, having used only Internet Explorer, the user has no real way to know what it means for a browser to be better. ${ }^{133}$ There may also be a natural reluctance to take on additional learning costs associated with using a different browser. OEMs may also refrain from the additional support costs that are associated with offering another browser.

Nevertheless, the damage that consumers may incur from the joint distribution of Internet Explorer with Windows is very limited. In the particular case of the browser, as contrasted with the media players, there is almost full compatibility between the various browsers. ${ }^{134}$ Additionally, Firefox provides a plug-in that emulates Internet Explorer and can even be used for live updates from Microsoft that require Internet Explorer. ${ }^{135}$ As with the media player analysis, there are no damages because of price competition since all the browsers are distributed for free. Additionally, the almost full compatibility of browsers implies that the benefits of variety and quality will be smaller than in the

133 See Samuelson \& Zeckhauser, supra note 129, at 7 (discussing how behavioral law and economics have emphasized the consideration of status quo bias in envisioning consumer behavior). On the importance of heuristics and biases in analyzing behavior, see generally JUDGMENT Under UnCERTAinty: Heuristics AND BiAses (Kahneman et al. eds., 1982).

134 Compatibility is ensured by the adherence to common and open standards published by W3C. See W3C, Web Design and Applications, http://www.w3.org/standards/webdesign/ (last visited Apr. 8, 2010). Of course, these are evolving standards and one browser may implement a new web page rendering standard while another may not. So there may be differences in appearance depending on implementation, especially if the source code of a page is written in the newest standard.

135 See Mozilla, Firefox Add-ons, https://addons.mozilla.org/en-US/ firefox/addon/35 (last visited Apr. 6, 2010). 
media player market. Thus, it seems likely that imposition of the "must carry" remedy is out of proportion in this case.

Where the effects on consumers are more substantial, the "must carry" remedy might be an appropriate remedy, although it could face some practical difficulties. For example, in the U.S. Microsoft case, the court considered requiring Microsoft to distribute Java. ${ }^{136}$ However, the court found that a "must carry" requirement would not provide a substantial benefit to competition once Microsoft's anticompetitive restraints on other channels of Java distribution were lifted by the other parts of the court's remedy (exclusivity arrangements). ${ }^{137}$ However, the primary reason for the court's reluctance was its uneasiness in granting a specific competitor, Sun Microsystems, an advantage in its efforts to compete with Microsoft that was not accorded to other competitors in the industry. The court noted that "favoritism of one market participant over another in a remedy provision places the court in the improper position of exerting too much control over the market." ${ }^{38}$ An adequate remedy would have to provide equal treatment to third parties in order to restore competition. For example, complainants should not be the only ones receiving the benefits of a "must carry" obligation: any firm that is capable of challenging the dominant firm should be included in the design of this obligation. It follows that for the "must carry" obligation to function equitably, new products should also be periodically included. This could raise some practical difficulties, such as which browsers to include and on what license terms, when there are five main browsers and several others from niche players. Also, the release schedule of these browsers must be aligned with the release schedule of Windows through further negotiation between the parties.

Negotiations between the Commission and Microsoft on whether to implement a version of a "must carry" rule gave

${ }^{136}$ State of New York v. Microsoft Corp., 224 F. Supp. 2d 76, 188-90

(D.D.C. 2002).

137 Id. at 189.

138 Id. 
rise to important recent developments. As previously explained, the Commission opened formal proceedings on Opera's complaint in December 2007 and issued a Statement of Objections to Microsoft in January 2009. ${ }^{139}$ To terminate the Commission's current investigation in the Internet Explorer case, Microsoft initially announced that it would not distribute the standard Windows 7 in Europe. ${ }^{140}$ Instead, it intended to produce and distribute in Europe solely a special edition of Windows 7 called Windows $7 \mathrm{E}$ which would not have Internet Explorer or any other browser pre-installed, adopting the removal approach of the Windows XP N remedy imposed by the Commission in the Windows Media Player case, as the sole version of Windows in Europe. OEMs would have the option to install a web browser of their choice as the default as well as include other browsers before the PC reached the final consumers. ${ }^{141}$

As part of Microsoft's initial proposal, European consumers who bought an upgrade to Windows 7 for Windows Vista or XP, or bought Windows 7 to install from scratch on a "naked" computer (which comes from the manufacturer without an operating system) would be given a version of Windows $7 \mathrm{E}$ that would include a file transfer protocol (FTP) link to a website from which they could download and install Internet Explorer 8. The Commission applauded Microsoft's steps to provide OEMs more

139 See Press Release, Eur. Comm'n, Competition: Statement of Objections to Microsoft for Non-Compliance with March 2004 DecisionFrequently Asked Questions (Mar. 1, 2007), http://europa.eu/rapid/press ReleasesAction.do?reference=MEMO/07/90\&format=HTML\&aged=0\&lang uage $=E N \& g u i L a n g u a g e=e n ;$ Microsoft Corp., Annual Report (Form 10-K), at 68-70 (July 30, 2009).

140 Matthew Newman, Microsoft Is Said to Be in Talks to Settle EU Cases, BloomberG, July 7, 2009, http://www.bloomberg.com/apps/news? pid=newsarchive\&sid=abzAzMCoi3Rw.

${ }^{141}$ Press Release, Eur. Comm'n, Antitrust: Commission Statement on Microsoft Internet Explorer Announcement (Jan. 12 2009), http://europa. eu/rapid/pressReleasesAction.do?reference=MEMO/09/272\&format=HTML \&aged $=0 \&$ language $=E N \&$ guiLanguage $=e n$. 
flexibility, but was critical of Microsoft's decision on the distribution of the retail upgrade or retail clean install. ${ }^{142}$

Based on that public feedback, as well as on private discussions, Microsoft withdrew its unilateral plan of distributing Windows $7 \mathrm{E}^{143}$ and proposed a final resolution in which it committed ${ }^{144}$ to (i) distribute a "ballot screen" (actually a "choices screen") through software update ${ }^{145}$ to European users of Windows XP, Windows Vista, Windows 7, and Windows client PC operating systems and (ii) allow both OEMs and users to turn on or off Internet Explorer. ${ }^{146}$ Thus, Microsoft's proposed remedy was not limited to Windows 7 . The European Commission received comments from third parties and finally accepted Microsoft's commitments by adopting an Article 9 Regulation 1/2003 decision on 16 December 2009. ${ }^{147}$

This remedy may have far-reaching consequences on the structure of the web browser industry and the distributional advantage of Internet Explorer. The choice screen will give those users who have set Internet Explorer as their default web browser an opportunity to choose whether and which competing web browser (or browsers) to install in addition to the one they already have. ${ }^{148}$ Users will be able to select one

142 Id.

${ }^{143}$ Dave Heiner, Microsoft on the Issues, Windows 7 and Browser Choice in Europe, http://microsoftontheissues.com/cs/blogs/mscorp/archive/ 2009/07/31/windows-7-and-browser-choice-in-europe.aspx (last visited Apr. 8, 2010).

144 Press Release, Microsoft Corp., Proposed Commitment (July 24, 2009), available at http:/www.microsoft.com/presspass/presskits/eu-msft/ docs/07-24-09Commitment.doc [hereinafter Commitment].

145 The words "ballot screen" were used inappropriately in the preliminary design of the remedy; the appropriate words are "choices screen." There is no ballot here and there is no decision by majority or any other rule that will be imposed on all participants. The screen will allow each consumer to set the default browser of their choice and allow the consumer to uninstall Internet Explorer.

146 See Microsoft Corp., Proposal Document Annex A (July 24, 2000), http://www.microsoft.com/presspass/presskits/eu-msft/docs/ANNEX_A.doc (detailing how this will be implemented in Windows 7).

${ }^{147}$ E.U. Microsoft II, supra note 7.

148 Commitment, supra note 144, II 8. 
or more of the web browsers offered through the choices screen. Microsoft has committed to distribute and install the choice screen software update "in a manner that is designed to bring about installation of this update at a rate that is as least as high as that for the most recent version of Internet Explorer offered via Windows Update." 149 The Commission' decision also emphasized that:

nothing in the design and implementation of the Choice Screen and the presentation of competing web browsers will express a bias for a Microsoft web browser or any other web browser or discourage the user from downloading and installing additional web browsers via the ChoiceScreen and making a web browser competing with a Microsoft web browser the default. ${ }^{150}$

The design of the choice screen attempts to represent as best as possible actual consumer preferences. At the same time, it avoids providing an excessively large choice that would have occupied a lot of disk space. The choices screen will be populated with the twelve most widely used web browsers that run on Windows 7 as measured semi-annually by averaging monthly usage share data for the previous six months for which data is available, with only one browser per vendor listed and shares for different released versions of the same vendor's browsers added together to determine the browser's total usage share. ${ }^{151}$ That will not include Internet Explorer "or any other browser which is based on Internet Explorer's rendering engine and the development or distribution of which is funded in whole or in substantial part by Microsoft." 152 The choices screen will display icons and the basic identifying information of the web browsers in a horizontal line and in an unbiased way. ${ }^{153}$ In addition, the choices screen will prominently display the final releases of

\begin{tabular}{|c|c|}
\hline & Id. II 9 \\
\hline & Id. II 10. \\
\hline & Id. III 11,14 \\
\hline & Id. II 14. \\
\hline
\end{tabular}


the five web browsers with the highest usage share in the EEA, the remaining seven being displayed in a random order if the user scrolls sideways. ${ }^{154}$ In order to ensure a higher degree of transparency, only those web browsers included in at last two of the three data sources for usage share information for web browsers (ComScore, NetApplications and StatCounter) would be considered for the choices screen. These will be ranked according to the arithmetic means of their numerical ranks in the data sources, taking into account their best ranking in two data sources. ${ }^{155}$ The Commission Decision also specified that "Microsoft will bear the costs of the technical implementation of the remedy in Windows and may not charge for the inclusion of a third party web browser in the Ballot Screen." 156

The choice screen remedy is limited to web browsers and any web browser vendor eligible to appear on the choice screen should refrain from installing additional software in the same download. Microsoft has to include the promotion of competing browsers, but does not have to distribute the code of third parties' browsers. The duration of the commitment is five years, leaving a wide window of opportunity to Microsoft's rivals, and in particular Google, to take hold of a significant part of the web browser market.

Microsoft will ensure that if Internet Explorer is turned off, then (i) it can only be turned on through user action specifically aimed at turning on Internet Explorer; (ii) the user interface cannot be called upon by applications; and (iii) no icons, links or shortcuts or any other means will appear within Windows to start a download or installation of Internet Explorer. ${ }^{157}$

A website will provide all necessary information about turning on or off Internet Explorer. In addition, Microsoft

\footnotetext{
154 Id.

155 Id. II 14.

156 Id.

157 Id. II 1.
} 
"will maintain that [website] so that other browser vendors can link to it if they wish." ${ }^{58}$ In essence, the "OEMs will be free to pre-install any web browser (or browsers) of their choice on PCs they ship and to set any browser as the default web browser."159 Microsoft has also committed "not to retaliate against any OEM refraining from developing, using, distributing, promoting or supporting any software that competes with Microsoft web browsers" through an alteration of commercial relations with that OEM, or by withholding the application of preferential terms, or finally by entering into any agreement with an OEM that conditions the grant of any monetary payment, discount, or the provision of preferential licensing terms or any other preferential treatment on the choice of Internet Explorer. ${ }^{160}$

In many ways, the European Commission's proposed outcome is similar to that of the United States consent decree. The United States consent decree allowed OEMs and final consumers to choose the default browser; similarly, OEMs and final consumers will choose the default browser in Europe. But there are also important differences. ${ }^{161}$

First, the United States consent decree was broader since it applied to all middleware, while the proposed E.U. outcome covers only browsers. Besides browsers, middleware includes email clients, audio-players, instant messengers, Java, and other software that functions between the operating system and applications.

Second, unlike in the United States, where all final consumers are given the opportunity to choose a default browser (and other middleware) through a "set defaults" screen, ${ }^{162}$ Microsoft's commitment in Europe will give a choice of browser to final consumers only if their computer

158 Id.

159 Id. II 2.

160 Id. III 4-5.

161 State of New York v. Microsoft Corp., 224 F. Supp. 2d 76, 273

(D.D.C. 2002).

162 Id. 
has Internet Explorer set as the default browser. ${ }^{163}$ If the computer manufacturer has set up a browser other than Internet Explorer as the default, the final consumer will not be presented with the E.U. choice screen or the "set defaults" screen available to United States consumers. Thus, the mechanism is tilted (1) against Microsoft, since computers with a non-Internet Explorer default will not offer consumers a choice of browsers like that offered with a computer loaded with Internet Explorer, and (2) in favor of non-Microsoft commercial browser vendors (Chrome, Opera, Safari, etc.) who can compensate OEMs to set up their browser as a default and then will not have their browser potentially removed via a choice screen. This may favor non-Microsoft browser vendors that have the deepest pockets.

Third, in the proposed E.U. outcome, Microsoft is obligated to line up many competitors' browsers for the final consumer to choose from. Thus, the Commission's proposed outcome is a choice screen rule imposed on Microsoft, especially since it applies only to computers where the OEM has installed Internet Explorer as the default. In the United States middleware default set-up screen, the consumer is faced with a list of browsers chosen by his computer's manufacturer. ${ }^{164}$ Depending on the computer manufacturer's choices, this list could be extensive, but could also be limited to a single browser (Internet Explorer or another one) and the consumer would need to take extra steps to download other choices.

163 In the European Union, final users will be automatically prompted to choose a browser if their computer came with Internet Explorer as the default, while in the United States they are not automatically prompted but just have the option of choosing between defaults. See Heiner, supra note 143 ("Shortly after new Windows PCs are set up by the user, Microsoft will update them over the Internet with a consumer ballot software program. If Internet Explorer is the default browser, the user will be presented with a list of other leading browsers and invited to select one or more for installation."). No choices screen will appear to users if Internet Explorer is not the default browser.

164 See State of New York v. Microsoft Corp., 224 F. Supp. 2d 76, 273 (D.D.C. 2002). 
Fourth, the proposed E.U. outcome allows OEMs and consumers to uninstall more layers of Internet Explorer, if they wish, than just the front end of Internet Explorer that the United States decree allows. In the proposed E.U. outcome, an OEM may choose never to show the existence of Internet Explorer to the final customer. Even so, deeper layers of the Internet Explorer API will remain in Windows when Internet Explorer is "off" and an applications manufacturer will be able to call and utilize the Internet Explorer API for both the "on" and "off" Internet Explorer functions. Additionally, users can always 'turn on' Internet Explorer even if the OEM has turned it off. OEMs cannot permanently disable Internet Explorer. ${ }^{165}$

Fifth, for an OEM that has chosen a default browser other than Internet Explorer in Europe, operating system and security updates will not appear to be carried out through Internet Explorer. That is, even if Internet Explorer is used to update software in the background, the consumer will see an interface that does not mention Internet Explorer. ${ }^{166}$

\section{Would a Structural Remedy Have Been an \\ Appropriate Solution to the Microsoft Antitrust Problem?}

In thinking about a potential structural remedy in the E.U. case, it is worth discussing how it was imposed in the United States case. This is because in both cases, the main issue involved Microsoft leveraging monopoly power to a market of a complementary good.

In United States v. Microsoft, Judge Jackson adopted the plaintiff's remedies proposal word-for-word and imposed a breakup of Microsoft into two "Baby Bills," 167 an operating

165 See Commitment, supra note 144, II 7.

166 This means that the Windows updates will be provided in the same way they are provided today in Vista and in Windows 7 Release Candidate.

167 This is a word play on "Baby Bells" that came out of AT\&T and the first name of the co-founder and then CEO of Microsoft, Bill Gates. 
systems company which would inherit all the operating systems software, and an "applications" company with all the remaining software assets. Cash and securities holdings of other companies held by Microsoft would have been split between the resulting entities. Bill Gates and other officers of the company would not have been allowed to hold executive and ownership positions in both of the resulting companies. ${ }^{168}$

In arguing for the break-up, the government put forward a number of reasons. ${ }^{169}$ But, since there was only an extremely short formal hearing on remedies, there was no chance for both the government's and Microsoft's cases on remedies to be discussed and evaluated. ${ }^{170}$ The government and the judge have stated (formally and informally) the following arguments for a breakup: ${ }^{11}$

1. That they considered the repeated violations of antitrust law by Microsoft as an indication that Microsoft would not follow any conduct or contractual restrictions; ${ }^{172}$ in fact, in some informal remarks, government officials believe that they were "tricked"

168 For a more detailed evaluation of the final United States remedy, see Nicholas Economides, Comment of Nicholas S. Economides on the Revised Proposed Final Judgment (Jan. 22, 2002), available at http://www.usdoj.gov/atr/cases/ms_tuncom/major/mtc-00022465.htm.

169 See generally Plaintiffs' Proposed Final Judgment, United States v. Microsoft, 215 F. Supp. 2d 1 (D.D.C. 2002) (Civ. Nos. 98-1232, 98-1233), available at http://www.justice.gov/atr/cases /f219100/219106.htm.

170 The hearing on remedy was on May 24, 2000. It started at 10:15 am, ended around 3:30 pm, and included a two-hour lunch break. See Open Law: The Microsoft Case, United States $v$. Microsoft: Trial Transcripts and Exhibits, http://cyber.law.harvard.edu/msdoj/trial.html (last visited Apr. 8, 2010).

171 See Plaintiffs' Proposed Final Judgment, supra note 169.

172 United States v. Microsoft Corp., 97 F. Supp. 2d 59, 62 (D.D.C. 2000) ("Second, there is credible evidence in the record to suggest that Microsoft, convinced of its innocence, continues to do business as it has in the past, and may yet do to other markets what it has already done in the PC operating system and browser markets. Microsoft has shown no disposition to voluntarily alter its business protocol in any significant respect."). 
by Microsoft in settling the 1995 case with terms that Microsoft was able to exploit; ${ }^{173}$

2. That the lack of remorse by Microsoft's executives was a clear indication that Microsoft "could not be trusted" to implement any other remedy; ${ }^{174}$

3. That the breakup was a "surgical cut" that would create the least interference with business; ${ }^{175}$

4. That as AT\&T and the rest of the telecommunications industry benefited from AT\&T's breakup, so Microsoft and the software industry were expected to similarly benefit since both industries have network effects;

5. That the breakup would have eliminated the incentive for vertical foreclosure; and

6. That the breakup would have reduced the "applications barrier to entry" since now the applications company might write popular Microsoft applications (such as MS-Office) for other platforms.

The government failed to show that the proposed (and later abandoned) breakup was the appropriate remedy. The Department of Justice did not perform the appropriate costbenefit analysis to show that conduct remedies were not sufficient and that a breakup is necessary. None of the

173 Id. ("Third, Microsoft has proved untrustworthy in the past. In earlier proceedings in which a preliminary injunction was entered, Microsoft's purported compliance with that injunction while it was on appeal was illusory and its explanation disingenuous.").

${ }^{174}$ Id. ("First: despite the Court's Findings of Fact and Conclusions of Law, Microsoft does not yet concede that any of its business practices violated the Sherman Act. Microsoft officials have recently been quoted publicly to the effect that the company has 'done nothing wrong' and that it will be vindicated on appeal. Indeed, it has announced its intention to appeal even the imposition of the modest conduct remedies it has itself proposed as an alternative to the non-structural remedies sought by the plaintiffs.").

175 See generally Decl. of Carl Shapiro, United States v. Microsoft Corp., 97 F. Supp. 2d 59 (Civ. Nos. 98-1232, 98-1233) (Apr. 28, 2000), available at http://www.justice.gov/atr/cases/f219100/219127.htm. 
affidavits in the remedies phase even approached a discussion on evaluating alternatives. Additionally, a few weeks before Judge Jackson's decision, under the supervision of Judge Posner ${ }^{176}$ the government and Microsoft had reached a compromise that imposed only conduct remedies. ${ }^{177}$ The government failed to justify why it was ready to compromise a few weeks earlier (in the settlement negotiated by Judge Richard Posner who was asked to try to find a settlement by Judge Jackson), on behavioral remedies but later claimed that structural remedies were necessary. Harry First notes that the plaintiffs would have been probably more successful "had they clearly such a remedy in mind at an earlier stage in the proceeding." 178

The first argument of the government in support of a breakup does not stand to reason. The 1995 case was settled with a decree that explicitly stated that Microsoft can include in its operating system any additional functionality. ${ }^{179}$ It is reasonable that Microsoft (or any observer, including the Department of Justice) would believe, given the 1995 consent decree, that adding browser functionality to Windows does not violate the consent decree. ${ }^{180}$ This, of course, does not mean that adding such functionality does not violate antitrust law in general, but it

176 See Joe Wilcox, Major Setback in Microsoft Settlement Talks, CNET NEWs, Apr. 1, 2000, http://news.cnet.com/2100-1001-238717.html.

177 The settlement was rejected by the States. See Julian Goldsmith, Nine States Reject Microsoft Settlement, SiliCoN, Nov. 7, 2001, http://www. silicon.com/technology/hardware/2001/11/07/nine-states-reject-microsoft-se ttlement-11028939/.

178 First, supra note 87, at 32.

179 See United States v. Microsoft, 59 Fed. Reg. 42, 845-02, 42, 855 (1994) ("Microsoft shall not enter into any License Agreement in which the terms of that agreement are expressly or impliedly conditioned upon: (1) the licensing of any other Covered Product, Operating System Software product or other product (provided, however, that this provision in and of itself shall not be construed to prohibit Microsoft from developing integrated products).") (emphasis added).

180 The dispute regarding the application of the 1995 consent decree ended with a D.C. Circuit ruling in favor of Microsoft's understanding of the meaning of the decree. United States v. Microsoft Corp., 147 F.3d 935 (D.C. Cir. 1998). 
puts to its death the idea that the government was tricked by Microsoft. The fact that companies and antitrust enforcers often have an asymmetry of information is very common and expected, and cannot be considered a trick, or a reason not to enter into agreements between antitrust authorities and companies.

The second argument of the Department of Justice in support of the breakup seems excessive. Antitrust enforcement is not an emotional tug of war in which the egos of either the plaintiffs or the defendants need to be satisfied. The show of remorse or lack thereof by Microsoft executives could not possibly define the remedy. We find it hard to believe that the judge would be correct in finding a different remedy appropriate if enough Microsoft executives simply showed public remorse. Moreover, Microsoft, like any other defendant, had a right to appeal (and it did so). A defendant's belief that he will prevail on appeal should not result in punishment.

The third argument, that the breakup is a surgical cut and therefore would have disrupted the industry the least, is countered by the facts. A breakup of Microsoft would have eliminated Microsoft as a flexible and formidable competitor. The wholehearted endorsement of the breakup by Microsoft's competitors in servers and back office (who were not found in United States $v$. Microsoft to have incurred damages by the Windows monopoly but who would have greatly benefited from the confusion and disruption created by a Microsoft breakup) is evidence that the breakup would have been one of the most disruptive possible outcomes. ${ }^{181}$ Generally breakups of large companies are complicated and drawn-out affairs that disrupt the company that is broken up, the producers of complementary goods to its products, and its customers.

181 See Wylie Wong, Oracle Chief Defends Microsoft Snooping, CNET NEWs, Jun. 28, 2000, http://news.cnet.com/Oracle-chief-defends-Microsoftsnooping/2100-1001_3-242560.html; see also Dan Goodin \& Dawn Kawamoto, Foes Take Microsoft to Task, CNET NEws, Mar. 3, 1998, http:// news.cnet.com/Foes-take-Microsoft-to-task/2100-1023_3-208653.html?tag= mncol. 
The fourth argument, that, since AT\&T's 1982 breakup was successful, Microsoft's would also be successful, was also incorrect. AT\&T was divided into the long-distance company (AT\&T), and seven regional operating companies, each of which remained a regulated local telecommunications monopoly until 1996. The destruction of AT\&T's longdistance monopoly encouraged competition, which brought sharply lower prices and immense consumer benefits. ${ }^{182}$ There are a number of key differences between the two companies and their competitive situations. And these differences make it very likely that a Microsoft breakup, besides harming Microsoft, would have harmed consumers and the computer industry. ${ }^{183}$

In 1981, AT\&T was a 100-year-old regulated monopoly with many layers of management. For historical reasons, the local phone companies within the old AT\&T, such as New York Telephone, were managed separately from the "long lines" division. Thus, it was not difficult to separate the divisions since they functioned on many levels as separate companies. AT\&T also had an abundance of managers to help cope with the breakup. ${ }^{184}$ By contrast, Microsoft is a young, entrepreneurial company run by few top executives, and its divisions are fluid. While this has made Microsoft an efficient and successful company, it also means that a breakup would have posed significant managerial problems and severely reduced the company's flexibility. Finally, AT\&T was a regulated utility, and regulation guaranteed that the companies emerging from the breakup stayed interconnected. ${ }^{185}$ In contrast, the Microsoft breakup would

${ }^{182}$ See Nicholas Economides, Telecommunications Regulation: An Introduction, in THE LIMITS AND COMPLEXITY OF ORGANIZATIONS 48, 55-57 (Richard R. Nelson ed., 2005).

${ }_{183}$ See Economides, supra note 92, at 7-39.

184 See generally ROBERT W. CRANDAll, Changing the RUles: TEChNological Change, INTERNATIONAL COMPETITION, AND REGULATION IN Communications (1989); Nicholas Economides, The Telecommunications Act of 1996 and Its Impact, 11 JAPAN \& WORLD ECON. 455 (1999).

${ }_{185}$ See Crandall, supra note 184; see also Roger G. Noll and Bruce M. Owen, United States v. AT\&T: The Economic Issues, in The ANTITRUst REVOLUTiOn 290, (J. Kwoka \& L. White eds., 1989). 
likely have lead to incompatibilities and further loss of efficiency. ${ }^{186}$

The Department of Justice's two-way breakup plan was premised on the hope that an autonomous applications company would create a new operating system to compete with Windows. But at trial it was stipulated that more than 70,000 applications ${ }^{187}$ run on Windows, creating what the government called "the applications barrier to entry" in the operating-system market. ${ }^{188}$ The new applications company, however capable, is unlikely to be able to single-handedly create a successful rival operating system in short order.

The breakup of Microsoft, which, after the DC Court of Appeals decision, was not pursued by the government, would have had detrimental effects. First, the breakup was likely to result in higher prices. If the Department of Justice was correct and Microsoft kept its OS prices low so that it could exercise its monopoly power in the adjacent browser market, the post-breakup Baby Bill that would inherit the operating system would have had no incentive to keep the price low. The OS Baby Bill would no longer have the incentive to disadvantage any applications companies. Thus, if the Department of Justice's theories are correct, the OS Baby Bill would have exercised its monopoly power and raise the price of the operating system to the detriment of consumers. If the Department of Justice was correct and Microsoft has significant monopoly power because of the applications barrier to entry and network effects, ${ }^{189}$ higher prices would be the direct result of the breakup. Second, as explained

186 The companies that would emerge from a Microsoft breakup would all have the same intellectual property, so their products would be compatible. However, each company would have a strong incentive to create incompatibilities to differentiate its offerings and be able to increase its price to cost and profit margins.

187 Finding of Facts II 40, United States v. Microsoft, Civ. No. 98-1233 (1998), available at http://www.justice.gov/atr/cases/f2600/2613-1.htm\#III.

188 Id. III 36-49.

189 See Decl. of Franklin M. Fisher, United States v. Microsoft, available at http://www.justice.gov/atr/cases/f212700/212766.htm. 
above, the breakup would likely eliminate the efficiencies that make Microsoft a flexible and formidable competitor.

A breakup would likely temporarily eliminate the incentive for interference between OSs and applications. Of course, the same goal has been accomplished by conduct restrictions without the cost and the disruption of a breakup. Moreover, the district court's breakup proposal did not impose permanent restrictions on the post-breakup functions of the resulting companies. The two Baby Bills would have been able to enter into each other's business soon after the breakup. It is very likely that a few years after such a breakup, one of the resulting companies would dominate both markets.

\section{Alternative Remedies}

The difficulty of devising adequate remedies that address both the application entry barrier issue and the distributional advantage of Windows, combined with the alleged "failure" of the traditional conduct remedies employed in this case ${ }^{190}$ led some commentators to suggest alternative and unconventional remedies, including nonantitrust alternatives.

\section{Public Procurement Procedures as an Antitrust Remedy: Reducing the Applications Barrier}

Regulation is not the only mechanism by which states can intervene in the marketplace. Increasingly, state ownership and/or state contracting/spending are employed in order to achieve specific public policy objectives, such as improving competition in the marketplace. ${ }^{191}$ Professor Herbert Hovenkamp suggested the possibility of using public contracting as a tool to reduce Microsoft's applications barrier to entry. He cited the example of Alcoa, where Alcoa was excluded from an auction for government-owned

190 Carl Shapiro, Microsoft: A Remedial Failure, 75 AnTITRUST L.J. 739 (2009).

191 See Christopher McCrudden, Buying Social Justice (2007). 
aluminum plants in a sale conducted pursuant to the Surplus Property Act, which "required the government to consider the impact on competition whenever it sold a significant piece of private property to a private firm."192 According to Hovenkamp, "[t]oday the government could do something similar by requiring its departments and agencies to use open-source software as an alternative to Microsoft's products." 193

This would increase the open source software installed base, since governments are among the principal purchasers of software products. It would help the economy move from a monopolized to a competitive computer platform network. The benefits for innovation could be particularly important, as recent studies have shown that innovation incentives (investments in applications) are sometimes greater for open source than for proprietary software platforms. ${ }^{194}$ Microsoft would be able to participate in the government bidding process as long as it offered an open source software product, either by developing new products or by making public the source code of Windows. The exclusion of Microsoft from the auction process if it did not offer open source products or if it did not guarantee a wide interoperability with all existing or new formats may improve efficiency in two ways. It may improve allocative efficiency, as the government would also be able to purchase software products at a lower price (not including remuneration for intellectual property rights), and dynamic efficiency, with increased competition between different products (assuming that a competitive market is better suited for innovation in software products than a monopolistic market). Of course, any imposed restriction of software choice would also precipitate reductions in utility of government users, at least in the short run. These utility

192 Herbert HovenKAMP, The ANTITRUst EnTERPRISE 302 (2005).

193 Id.

194 See, e.g., Nicholas Economides \& Evangelos Katsamakas, Linux $v$. Windows: A Comparison of Application and Platform Innovation Incentives for Open Source and Proprietary Software Platforms, in THE Economics of Open Source Software Development 207 (Juergen Bitzer \& Philip J.H. Schroeder eds., 2006). 
losses of the Hovenkamp proposal have to be considered and balanced with the potential benefits outlined above. ${ }^{195}$

The decision of the Brazilian government to switch from Microsoft proprietary software to open source software and to pass legislation making the use of open source software mandatory for governmental departments was reportedly aiming to force Microsoft to rethink its business model. ${ }^{196}$ The German government has also adopted guidelines for federal, state, and local governments as well as other public sector agencies interested in migrating from Microsoft proprietary technology to open source software and signed contracts with IBM for computer systems based on Linux operating systems. ${ }^{197}$

These initiatives may have influenced Microsoft's progressive commitment with interoperability and probably led to the publication of the "interoperability principles." 198 An example may be the interoperability of Microsoft's formerly proprietary OOXML (Office Open XML file format), now a formal ISO standard, ${ }^{199}$ with the OpenDocument

195 Additionally, it would be far reaching into the realm of industrial policy if the government specified a particular model of software development predicting what finished software products provide the greatest value per dollar spent. If Microsoft were forced to make the Windows source code public, it would reduce Microsoft's incentives to drive that product forward with new innovations as others could then offer essentially the same product for free, possibly only subject to the risk of patent infringement suits. Also, there is no significant evidence that the open source model can become a replacement for for-profit software. See Nicholas Economides \& Evangelos Katsamakas, Two-Sided Competition of Proprietary vs. Open Source Technology Platforms and the Implications for the Software Industry, 52 MGMT. ScI. 1057 (2006); see also Economides \& Katsamakas, supra note 194.

196 See Steve Kingstone, Brazil Adopts Open-Source Software, BBC NEWs, June 2, 2005, http://news.bbc.co.uk/2/hi/business/4602325.stm.

197 See IBM Signs Linux Deal with Germany, BBC News, June 3, 2002, http://news.bbc.co.uk/2/hi/business/2023127.stm.

${ }^{198}$ See Microsoft Corp., Interoperability Principles, http://www.micro soft.com/interop/principles/default.mspx (last visited Apr. 8, 2010).

199 See Press Release, Int'l Org. for Standardization, ISO/IEC DIS 29500 Receives Necessary Votes for Approval as an International 
Format (ODF) standard, which is supported by Sun Microsystems, IBM, Novell, Nokia, Intel, and Red Hat. This led to the release of Microsoft Office 2007 service pack 2, a product that, according to Microsoft, "provides built-in support for more file formats than any other productivity suite on the market" and which comes with a "new programming interface that will make it easy for developers to make any other document format show up in the drop down menu and be selected by users as their default, putting it on a par with the major formats already supported in Office 2007."200 This business culture evolution may have been provoked by the recent competition law challenges on interoperability and the use of public procurement as a way to increase competition in the marketplace. The cumulative impact of these combined antitrust and non-antitrust remedies is outside the scope of this study and should be empirically examined.

\section{Standard Setting Organization and de Facto Versus de Jure Standardization}

The alleged de facto standardization of the Windows architecture work group computing environment or the Windows Media Player platform through the leveraging of Microsoft's dominant position in the operating systems market was a development that both the European Commission and the General Court abhorred. ${ }^{201}$ The General

Standard (Apr. 2, 2008), available at http://www.iso.org/iso/pressrelease. htm?refid $=$ Ref1123.

${ }^{200}$ Posting of Tom Robertson to Microsoft on the Issues, http://micro softontheissues.com/cs/blogs/mscorp/archive/2009/04/28/following-throughon-our-commitment-to-intero perability.aspx (Apr. 28, 2009, 09:06 EST) (last visited Apr. 8, 2010).

201 See Case T-201/04, Microsoft Corp. v. Commission, 2007 E.C.R. II3601, II 277. The Commission noted that the position of Microsoft on the client PC operating systems market will enable it to "determine to a large extent and independently of its competitors the set of coherent communications rules that will govern the de facto standard for interoperability in work group networks." But note that standardization to WMA and WMV never occurred, but was assumed by the Commission to 
Court was particularly clear that its reservations did not concern the process of standardization, which may provide benefits to consumers, but the way this de facto standardization took place in this particular case. The Court noted that "[a]lthough, generally, standardization may effectively present certain advantages, it cannot be allowed to be imposed unilaterally by an undertaking in a dominant position by means of tying." ${ }^{202}$

A possible alternative is to delegate the task of developing interoperable standards to a standard-setting organization (SSO), which will assist the competition law authority or court in implementing interoperability requirements, although there might be competition law issues involved in the operation of the $\mathrm{SSO} .{ }^{203}$ In this case, the standard will not emerge by a process of de facto standardization by a dominant firm but will be the outcome of negotiations. The SSO's activity will be closely monitored in order to avoid cartel-like behavior and deceptive conduct and to guarantee transparent and open procedures. ${ }^{204}$ However, this solution presents its own problems: the imbalance of power between Microsoft and its competitors in the standard setting body and the subsequent risk that the standard approved will not

be later disproved in actuality. Today, as well as before the imposition of the Windows-N remedy, WMA and WMV are not dominant media formats.

${ }^{202}$ Id. IIII 526, 1152.

${ }^{203}$ See Press Release, Eur. Comm'n Antitrust: Commission Market Tests Commitments Proposed by Rambus Concerning Memory Chips (June 12, 2009), available at http://europa.eu/rapid/pressReleasesAction. do?reference=MEMO/09/273\&format=HTML\&aged=0\&language $=E N \&$ gui Language $=$ en.

${ }^{204}$ See Philip J. Weiser, Regulating Interoperability: Lessons from AT\&T, Microsoft, and Beyond, 76 AnTITRUST L.J. 271, 298 (2009). Note, however, the rejection of the "truth-in-standards" provisions suggested by the non-settling states by the D.C. Circuit on the ground that these were unrelated to the violation found. The non-settling states would have required Microsoft to continue supporting any industry standard it has publicly claimed to support until it publicly disclaims such support, or the standard expires or is rescinded by the standard setting body, and to continue to support an industry standard any time it makes a proprietary alteration. 
be "sufficiently" interoperable with competitors' products. ${ }^{205}$ Additionally, the standard setting process is slow and could thus retard innovation along some dimensions while accelerating it along others. Furthermore, an agreement by competitors on a standard tends to restrict competition because competitors are limited largely to competing within the specific narrow confines of the standard. Breakthrough innovation with alternative approaches tends not to occur because everyone is focused on implementation of the standard.

\section{THE NEED FOR A PRINCIPLE OF REMEDIAL PROPORTIONALITY}

The principle of proportionality constitutes an important limit to the European Commission's discretion in imposing remedies. It is explicitly provided in Article 7 of Regulation $1 / 2003$ that any behavioral or structural remedies imposed by the Commission must be proportionate to the infringement committed and necessary to bring the infringement effectively to an end. ${ }^{206}$ This provision mainly

${ }^{205}$ See Paul Meller, Microsoft's ISO Win May Raise Antitrust Issues, PCWorLd, Apr. 2, 2008, available at http://www.pcworld.com/article/ 144036/microsofts _iso_win_may_raise_antitrust_issues.html. The article details the recent investigation by the European Commission of the interoperability of OOXML, which was approved as an ISO-recognized international standard in April 2008. However, there have been allegations which are currently being investigated by the European Commission that there have been irregularities or attempts to influence the vote at the European Committee for Standardization or the International Organization for Standardization, thus illustrating the difficulties of guaranteeing the transparency of the process.

${ }^{206}$ Council Regulation, supra note 12. According to Article 7:

1. Where the Commission, acting on a complaint or on its own initiative, finds that there is an infringement of Article 81 or of Article 82 of the Treaty, it may by decision require the undertakings and associations of undertakings concerned to bring such infringement to an end. For this purpose, it may impose on them any behavioural or structural remedies which are proportionate to the infringement committed and necessary to bring the 
relies on Article 3(1) of Regulation 17/62 (now replaced by Regulation 1/2003) that the remedies imposed should "not exceed what is appropriate" and should be "necessary to attain the objective sought, namely to restore compliance with the rules infringed." ${ }^{207}$ Structural remedies are generally disfavored, and generally may only be applied if there is no equally effective behavioral remedy or if any equally effective behavioral remedy would be more burdensome for the targeted firm. ${ }^{208}$ Article 23(2) of the Regulation creates a quantitative measure of proportionality, providing that the Commission may not impose fines that exceed ten percent of a firm's total turnover in the preceding business year (attempting to balance the magnitude of the anticompetitive harm against the harm the fine causes to the targeted firm). In addition, when determining the amount of the fine, the court must consider the gravity and the duration of the infringement as well as the effect of the competition law infringement on the market. ${ }^{209}$ The General Court has also recently applied the principle of proportionality to commitment decisions adopted under Article 9 of Regulation 1/2003: In Alrosa, the Court held that "the voluntary nature of the commitments . . . does not

infringement effectively to an end. Structural remedies can only be imposed either where there is no equally effective behavioural remedy or where any equally effective behavioural remedy would be more burdensome for the undertaking concerned than the structural remedy. If the Commission has a legitimate interest in doing so, it may also find that an infringement has been committed in the past.

2. Those entitled to lodge a complaint for the purposes of paragraph 1 are natural or legal persons who can show a legitimate interest and Member States.

207 See Case T-170/06, Alrosa Co. v. Commission, 2007 E.C.R. II-2601, II 102; Case T-338/94, Finnboard v. Commission, 1998 E.C.R. II-1617, II 242; Case T-76/89, ITP v. Commission, 1991 E.C.R. II-575, II 93; Case T7/93, Langnese-Iglo v. Commission, 1995 E.C.R. II-1533, II 209; Case T9/93, Schöller v. Commission, 1995 E.C.R. II-1611, II 163.

208 Council Regulation, supra note 12, at recital 12.

209 See Joined Cases C-189/02 P, C-202/02 P, C-205-208/02 P, \& C213/02 P, Dansk Rørindustri v. Commission, 2005 E.C.R. I-5425, II 243. 
relieve the Commission of the need to comply with the principle of proportionality, because it is the Commission's decision which makes those commitments binding" and that "giving that commitment, the undertakings concerned merely assented, for their own reasons, to a decision which the Commission has empowered to adopt unilaterally." 210 The Commission is subject to the same duty of applying the principle of proportionality in adopting Article 7 or 9 decisions, which also requires, in the case of Article 9, "an appraisal in concreto of the viability of those intermediate solutions" that were not finally chosen by the Commission. ${ }^{211}$

It is not clear if the Commission has appraised concretely in its Article 9 commitment decision in the Microsoft case the less onerous alternative remedies on offer, following the Alrosa precedent. $^{212}$ In any case, the choice screen remedy imposed is subject to the requirement of proportionality, which raises the issue of what exactly this requirement entails.

The principle of proportionality is defined in detail in Article 7 of Regulation $1 / 2003^{213}$ and in the competition law jurisprudence of the European courts. ${ }^{214}$ In order to satisfy the principle of proportionality, "measures adopted by Community institutions [must] not exceed the limits of what is appropriate and necessary in order to attain the legitimate objectives pursued by the legislation in question; when there

${ }^{210}$ Case T-170/06, Alrosa Co. v. Commission, 2007 E.C.R. II-2601 Iा 105-106, appeal docketed, Case C-441/07 P, Commission v. Alrosa Co.

${ }^{211}$ Id. If 156. The proportionality test is not thus limited to the abstract examination of the reasonableness of the specific final measure but also looks to the concrete existence of less restrictive (to the undertaking's freedom of action) ways of achieving the same purposes (intermediary solutions). But see Op. Advocate Gen., Case C-441/07 P, Commission v. Alrosa Co., not yet published, II 62 (arguing the contrary position).

212 Case T-170/06, Alrosa Co. v. Commission, 2007 E.C.R. II-2601.

${ }^{213}$ See Council Regulation, supra note 12.

214 Case T-170/06, Alrosa Co. v. Commission, 2007 E.C.R. II-2601, II 98. See also Case T-260/94, Air Inter v. Commission, 1997 E.C.R. II-997; Case T-65/98, Van den Bergh Foods v. Commission, 2003 E.C.R. II-4653, II 201. 
is a choice between several appropriate measures, recourse must be had to the least onerous, and the disadvantages caused must not be disproportionate to the aims pursued." 215 Proportionality is also a general principle of European Union law, applying as such to all measures adopted by European Union institutions. According to settled case law, "by virtue of that principle, the lawfulness of the prohibition of an economic activity is subject to the condition that the prohibitory measures are appropriate and necessary in order to achieve the objectives legitimately pursued by the legislation in question; when there is a choice between several appropriate measures, recourse must be had to the least onerous, and the disadvantages caused must not be disproportionate to the aims pursued."216 This three-prong proportionality test limits the discretion of the European Commission in adopting appropriate remedies. In that sense, proportionality differs from a cost-benefit analysis, which would focus only on the gravity of harm and the alternative remedies that might have been imposed. Under a cost-benefit analysis, a remedy would be disproportionate when its costs and burdens outweigh its likely benefit of restoring competition or when its costs would be more important than an alternative remedy, which would have also been equally effective. But proportionality may also take into account other issues, such as the degree of judicial deference to the Commission's decision, as "the appropriateness of and the need for the contested decision must be assessed in relation to the aim pursued by the institution." 217 Although the principle of remedial proportionality does not exist as such in United States antitrust law, a constitutional proportionality requirement

${ }^{215}$ Op. Advocate Gen., Case C-441/07 P, Commission v. Alrosa Co., II 46.

216 Case C-331/88, The Queen v Minister of Agric., Fisheries and Food ex parte Fedesa, 1990 E.C.R. I-4023, II 13.

217 Case T-170/06, Alrosa Co. v. Commission, 2007 E.C.R. II-2601, II 99. 
applies to most punitive damages cases as well as to other types of remedies. ${ }^{218}$

The first prong of the proportionality principle is of particular interest for our purposes. In order that the remedy be appropriate and necessary, the Commission must identify both the magnitude and scope (amount) of the harm to consumers/competition and the type of violation. "Type of violation" means both the specific competition law category (i.e., a refusal to deal, a tying case, an exclusive dealing case), and also the theory of harm advanced in the specific case (i.e., maintenance of monopoly, leveraging, essential facilities). ${ }^{219}$ The importance of remedial fit is often stressed by antitrust law literature. ${ }^{220}$ It relates to the causation link between the anticompetitive conduct and the theory of harm, which has, as the DC Circuit held in the US Microsoft case, "more purchase in connection with the appropriate remedy issue" than with the substantive issue of the establishment of the liability of the undertaking for an infringement of competition law. ${ }^{221}$

It is clear that remedies should be effective, in the sense that they should aim "to re-establish the competitive situation, i.e., the competitive process that would have prevailed but for the infringement." ${ }^{222}$ However, it is also

218 See generally E. Thomas Sullivan, Proportionality Principles IN AMERICAN LAW (2008); Tracy A. Thomas, Proportionality and the Supreme Court's Jurisprudence of Remedies, 59 HASTINGS L.J. 73 (2007).

${ }^{219}$ See Ioannis Lianos, Categorical Thinking in Competition Law and the "Effects-Based" Approach in Article 82 EC, in ARTICLE 82 EC: REFLECTIONS ON ITs RECENT Evolution 19 (Ariel Ezrachi ed., 2009).

${ }^{220}$ See Thomas O. Barnett, Section 2 Remedies: What to Do After Catching the Tiger by the Tail, 76 ANTITRUST L. J. 31, 36 (2009) ("[T]he remedy needs to be tied closely to the anticompetitive conduct occasioning it. That means that remedies need to be sufficient, but not overbroad, and proportional to the offense"); Gregory J. Werden, Remedies for Exclusionary Conduct Should Protect and Preserve the Competitive Process, 76 ANTITRUST L. J. 65, 65 (2009) (“[R]emedies for exclusionary conduct should arise organically out of the theory of the case") (citing Laurence A. Sullivan, HaNDboOK OF the LaW of ANTITRust 146 (1977)).

${ }^{221}$ United States v. Microsoft Corp., 253 F.3d 34, 80 (D.C. Cir. 2001).

${ }^{222}$ Per Hellström, Frank Maier-Rigaud, \& Friedrich Wenzel Bulst, Remedies in European Antitrust Law, 76 ANTITRUST L.J. 43, 58 (2009). 
clear that the principle of proportionality requires a close fit between the harm and the remedy. The suggestion that remedies may go beyond "mirroring the abuse" profoundly misunderstands the relation between the remedy and the right it is attempting to protect. ${ }^{223}$ One could conceive the right as being distinct from the provision of the remedies for violation of that right-in other words that there is a dichotomy between rights and remedies, each concept being conceptually isolated from the other. This formalistic position might lead the Commission and the national courts applying E.U. competition law not to impose any remedies for the infringement of a right (or wrong committed) or to impose stricter remedies than the nature and effect of the violation of the right would have required. For example, a remedy that would go beyond simply "mirroring the abuse" and would "give the infringer's competitors an advantage over the infringer in order to restore the competitive process" 224 goes beyond the wrong committed because of the abusive conduct. Such a punishment could eventually jeopardize the dominant position of the firm, which would be conceived as antithetical to the principle of the "competitive process," the dominant firm having the ability to behave independently from its competitors. However, Article 102 does not condemn dominant positions as such, nor does it restrict a dominant firm's ability to compete on the merits, as long as that situation does not qualify as an abuse. ${ }^{225}$ Remedies that go beyond mirroring the specific abuse could certainly be adopted in theory, but that should be done either by advancing an additional theory of harm/liability under Article 102 that is more directly linked to the remedy

${ }^{223} I d$. at 59.

224 Id.

225 Id. The authors' reasoning is based on an internal contradiction. They argue that remedies may go beyond mirroring the abuse, but at the same time, they qualify their statement by recognizing that the remedy "should not undermine the infringer's incentive to compete on the merits." Id. However, this is not very different from advancing that the remedy should mirror the abuse. Indeed, if the dominant firm competes on the merits, there is no abuse. 
sought or by employing another competition law instrument than Article 102..$^{226}$

An alternative view would be to consider that rights and remedies are profoundly interlinked with each other, so that the remedy is the measure of the right. This profoundly legal realist view would consider that "the nature of the remedy sought in an antitrust case is often an important clue to the soundness of the antitrust claim" (the "if you cannot fix it, it isn't broken" argument). ${ }^{227}$ Between these two poles, there is the principle of remedial proportionality, which we defend as being normatively desirable and recognized by positive law. Without adopting a strict dichotomy between the identification of the right (or the liability step) and the remedy, the principle of proportionality requires a close link between the two. In an economically informed interpretation of Article 102 this would require a fit between the theory of harm or the type of abuse and the remedy imposed: in the Microsoft case, a more explicit causal connection between the tying abuse category and the choice screen remedy that will eventually apply.

\section{CONCLUSION}

The success or the failure of the remedial action in the United States and the E.U. Microsoft case is still, five years after the D.C. Circuit decision on remedies in the United States and since the Commission's Decision, a matter of controversy. ${ }^{228}$ Some tend to link the alleged failure of the remedy, or its unexpected costs and scope, with the issue of

${ }^{226}$ A broader theory of abuse (and consumer harm) under Article 102 TFEU that would have a direct link with the remedies sought could be one option to deal with the problem in this case. Sector inquiries with the possibility of imposing effective remedies, market investigation references or a provision equivalent to Section 5 of the FTC Act could also be adequate tools in this case.

227 Brunswick Corp. v. Riegel Textile Corp., 752 F.2d 261, 267 (7th Cir. 1984).

228 Compare Carl Shapiro, Microsoft: A Remedial Failure, 75 Antitrust L.J. 739 (2009), with Keith N. Hylton, Remedies, Antitrust Law and Microsoft: Comment on Shapiro, 75 ANTITRUST L.J. 773 (2009). 
liability, professing what has been known as "if you cannot fix it, it isn't broken." Although it is clear that, in principle, the costs of remedies should not outweigh the consumer benefit they achieve, we contend that plaintiffs employ a sequential information model that addresses one issue at a time. It would be therefore inappropriate to dismiss a case simply because the plaintiff did not identify an adequate remedy. Harry First rightly observes "it seems inevitable that plaintiffs will refine their case as they learn more in the course of the litigation process," in particular in high tech industries where technological change is so complex and rapid that there is a need for quick action. ${ }^{229}$

At the same time, the litigation process is cheap compared to competition in price or product development. Thus, rivals have significant incentives to sue global dominant firms on multiple grounds and in multiple jurisdictions with the expectation that some suit will ultimately be successful in some jurisdiction. And, sometimes, one or more of these cases is picked up and pursued by an antitrust authority, as it happened with the two cases against Microsoft, one in the United States and one in the E.U. To some extent, the lack of fully-thoughtthrough remedies in both of these cases is a consequence of the history of the cases: they were started by allegations of rivals who were primarily interested in improving their competitive position vis-à-vis the dominant firm rather than remedying all the consequences of anti-competitive behavior.

The anticompetitive effects of these practices were clearly identified and a dominant narrative emerged as a retrospective rationalization of different practices and strategies adopted by Microsoft that harmed consumers: the maintenance of monopoly story in the United States case and the leveraging story in the E.U. case. The identification of a specific consumer harm story could operate as a limit to the identification of adequate remedies. Antitrust liability stories transcend the different stages of a case, including the issue of remedies that need to address the specific consumer

${ }^{229}$ First, supra note 87, at 31. 
harm. The United States Microsoft case was problematic in this respect as there wasn't a direct link between the antitrust liability story of maintenance of monopoly and the forward-looking remedies adopted. It is clear that Microsoft executives were concerned by the potential (but unlikely) erosion of the Windows' platform ubiquity from the joint actions of Sun and Java. The competitive threat to Windows did not materialize, but Microsoft raised the walls of its fortress preventively in order to defend its position from Java's and Sun's naval attack, if one employs Carl Schapiro's fortress metaphor. ${ }^{230}$ But, is it legitimate to require dominant firms to bring down the walls of their fortress or to keep them at the same level they were before, when they identify, perhaps wrongly, the existence of a potential threat of attack? Lowering the wall some centimeters will certainly be an option, but the question will be how much lower and for what reason.

In comparison, the narrative of the first European Microsoft case fits better with the remedies imposed. The issue here was that the dominant firm was using an existing fort to attack a new area and extend its fortification. The dominant firm would have thus been able to reinforce the defenses of its existing fort and to increase the risks for those attacking it. The remedy in this case seems more straightforward in comparison to the previous setting: terminating the extension of the fortification will bring the end of both the ambition to reinforce the existing fortifications and to occupy a new area.

What this metaphor shows is that the choice of the adequate narrative among different consumer harm stories should explain/correspond to the remedy sought. This was certainly the case with the E.U. Microsoft case but not with the United States Microsoft case, where the difficulty in convincing the courts to accept the leveraging argument, as well as the change of the administration and possibly the re- 
framing of the government's claim, ${ }^{231}$ led to the development of a narrative (maintenance of monopoly) that had only an indirect link with the bulk of the forward-looking remedies that were finally imposed.

This mismatch between the consumer harm story/narrative and the remedy sought is also manifest in E.U. Microsoft II. Although the Commission seemed to advance a consumer harm story based on the relatively favorable case law on tying, which establishes some form of quasi per-se illegality of tying if a company has a dominant position, the choice screen commitment accepted by the Commission as an adequate remedy for the competition problem does not address directly this particular risk of abuse. Unbundling would seem to be the most appropriate remedy for a leveraging/tying concern. However, the Commission reacted negatively when Microsoft decided to unbundle Internet Explorer from Windows 7-E. The choice screen remedy which was ultimately adopted fits more with an essential facilities case, where Windows would have been considered indispensable for the distribution of an Internet browser. We do not criticize the remedy per se, since it could prove to be effective in terms of reinvigorating competition in the Internet browser market, but rather the apparent conceptual mismatch between the consumer harm story and the remedy. It would be particularly damaging for the development of competition law and economic growth in general if plaintiffs could employ the less demanding (in terms of a standard of proof) theory of consumer harm in order to achieve the most far reaching remedies (in terms of commitments from a dominant firm). The problem cannot be solved by the characterization of the Microsoft case as a strictly "tying" case. The classification of abuses under Article 102 is not a clear-cut exercise, and there is always a

231 Harry First \& Andrew I. Gavil, Re-Framing Windows: The Durable Meaning of the Microsoft Antitrust Litigation, UTAH L. REV. 679, 682 (2006). 
fine conceptual line that distinguishes different categories of abuses if one takes an effects-based approach. ${ }^{232}$ 